\title{
Linking Alpine deformation in the Aar Massif basement and its cover units - the case of the Jungfrau-Eiger mountains (Central Alps, Switzerland)
}

\author{
David Mair, Alessandro Lechmann, Marco Herwegh, Lukas Nibourel, and Fritz Schlunegger \\ Institute of Geological Sciences, University of Bern, Baltzerstrasse 1+3, 3012 Bern, Switzerland \\ Correspondence: David Mair (david.mair@geo.unibe.ch) \\ Received: 28 May 2018 - Discussion started: 5 June 2018 \\ Revised: 13 August 2018 - Accepted: 27 August 2018 - Published: 25 September 2018
}

\begin{abstract}
The northwest (NW) rim of the external Aar Massif was exhumed from $\sim 10 \mathrm{~km}$ depth to its present position at $4 \mathrm{~km}$ elevation above sea level during several Alpine deformation stages. Different models have been proposed for the timing and nature of these stages. Recently proposed exhumation models for the central, internal Aar Massif differ from the ones established in the covering Helvetic sedimentary units. By updating pre-existing maps and collecting structural data, a structural map and tectonic section were reconstructed. Those were interpreted together with microstructural data and peak metamorphic temperature estimates from collected samples to establish a framework suitable for both basement and cover. Deformation temperatures range between 250 and $330^{\circ} \mathrm{C}$, allowing for semi-brittle deformation in the basement rocks, while the calcite-dominated sedimentary rocks deform in a ductile manner at these conditions. Although field data allow to distinguish multiple deformation stages before and during Aar Massif's exhumation, all related structures formed under similar $P, T$ conditions at the investigated NW rim. In particular, we find that the exhumation occurred during two stages of shearing in Aar Massif's basement, which induced in the sedimentary rocks first a phase of folding and then a period of thrusting, accompanied by the formation of a new foliation.
\end{abstract}

\section{Introduction}

The Aar Massif is the largest external crystalline massif (ECM) in the Alps, made up of exhumed pre-Triassic basement rocks and Mesozoic to Cenozoic sedimentary cover rocks along its northeast (NE)-striking frontal margin. In this region, the Eiger, Mönch and Jungfrau mountains in the Swiss Alps feature an immense topographic expression along this northwest (NW) rim, with north faces that are characterized by almost $1800 \mathrm{~m}$ of difference in elevation. Throughout their stepwise, pyramidal headwalls, these mountain ranges expose both the pre-Alpine crystalline substratum and its Mesozoic sedimentary cover. These scenic outcrops are thus key to understanding the massif's exhumation from $\sim 10 \mathrm{~km}$ depth to its present position at $4 \mathrm{~km}$ elevation above sea level. Therefore, these mountains have been the focus of a long tradition of structural research, which yielded a general picture of a steeply dipping autochthonous sedimentary cover in front of an up-domed ECM (e.g., Pfiffner, 2014).

Further to the NW are the detached fold-and-thrust nappes of the Upper Helvetics, the Alpine evolution of which is considered to have been decoupled from the massif's Alpine development in an early stage. The Helvetic units have experienced a phase of passive up-doming in response to the rise of the Aar Massif after their displacement into a frontal position in the NW during the Oligocene (e.g., Schmid et al., 2004; Hänni and Pfiffner, 2001). The lithostratigraphic and tectonic studies, which resulted in the reconstruction of this scenario, have been conducted over the course of more than 150 years (e.g., Escher von der Linth, 1839; Baltzer, 1880) and have mainly been focused on a few key regions of this ECM. These mainly include the south and southwest (SW) sectors of the Aar Massif (i.e., Krayenbuhl and Steck, 2009; Herwegh and Pfiffner, 2005; Steck, 1984, 1968) and the area surrounding the Jungfrau and the Mönch mountains (i.e., Rohr, 1926; Scabell, 1926; Collet and Paréjas, 1931; Günzler-Seifert and Wyss, 1938; Kammer, 1989 and refer- 
ences therein). Further to the NW, the neighboring Mesozoic sedimentary rocks have been studied in detail, an overview is found in Hänni and Pfiffner (2001), Menkveld (1995), Pfiffner (1993) and references therein.

The best-studied region of the Aar Massif is the Haslital, which stretches from Innertkirchen up to the Grimsel Pass (Abrecht, 1994 and references therein) and which exposes the crystalline rocks of what has been referred to as the central Aar Massif. New ${ }^{40} \mathrm{Ar} /{ }^{39} \mathrm{Ar}$ and $\mathrm{Rb} / \mathrm{Sr}$ ages for synkinematically formed fault zone micas (i.e., Challandes et al., 2008; Rolland et al., 2009; Schaltegger et al., 2003) together with structural observations (i.e., Wehrens et al., 2017, 2016) and K-Ar ages for fault zone micas (Berger et al., 2017a) advanced the understanding on the geodynamic evolution of the Aar Massif. A compilation of peak metamorphic temperature and deformation age data, as well as calcitedolomite geothermometry, culminated in a new model for the exhumation of this unit (Herwegh et al., 2017) and in a new regional-scale geological map (Berger et al., 2017b). Nevertheless, details about how the tectonic deformation affected the crystalline basement and the sedimentary cover rocks of Aar Massif, and if and how this deformation propagated into the sheared-off Helvetic nappe system in front of the massif, have not been explored in detail for the JungfrauMönch area. This is mainly due to the complexity of the geologic architecture and the inaccessibility of the area that have thwarted a precise reconstruction of the history of the frontal part of this massif. It is the scope of this paper to link the tectonic history of these uplifted basement blocks to the structures in the cover.

Here, we reconstruct the relative chronology of the frontal part of the Aar Massif in 3-D. We focus on the central part presently exposed in the central Swiss Alps, where this contact is exposed approximately $12 \mathrm{~km}$ along the strike of the basement cover interface (Fig. 1). We proceed through (i) establishing a synthesized lithostratigraphic framework for the region, (ii) collecting new structural data and samples on the surface and along the Jungfraubahn railway tunnel that crosses the mountain range and (iii) modeling the tectonic architecture with geographic information system (GIS) and Midland Valley's (now Petex) Move ${ }^{\mathrm{TM}}$ software package. We differentiate the sedimentary cover rocks based on stratigraphic criteria, which in turn allow us to reconstruct the geometry of the exposed units. Structural data enable us to unravel their relative deformation, while Raman spectroscopy of carbonaceous material (RSCM) yields estimates on peak metamorphic temperature. Our synthesis of existing data together with new observations finally allows us to link the fabric of the sedimentary cover rocks with the underlying basement units' evolution for some of the Alps' most famous sceneries. This results in a new picture of how the differences in rheology have controlled both mesoscale deformation structures and microscale deformation style as well as the bedrock fabric of the crystalline basement and the overlying sedimentary cover lithologies.

\section{Geological setting}

\subsection{Tectonic architecture}

The Aar Massif is made up of polymetamorphic preVariscan gneisses intruded by post-Variscan granitoids (Labhart, 1977; Abrecht, 1994). The most external polycyclic gneiss unit is exposed along Aar Massif's northwestern rim, referred to as the Innertkirchen-Lauterbrunnen zone (ILZ; Berger et al., 2017b; Abrecht, 1994; Fig. 2). Further to the southeast (SE), the Erstfeld zone (EZ) also exposes gneisses (Abrecht, 1994) and occurs in a hangingwall position to the ILZ (Berger et al., 2017b; Fig. 2) with sedimentary rocks squeezed in between these two gneiss units. This tectonic sliver made up of sedimentary and crystalline rocks is referred to as Jungfrau sediment wedge (JSW). Both units share a concordant overall SW-NE strike direction of structures such as lithological boundaries and foliations (Oberhänsli et al., 1988). These pre-Variscan basement units experienced multiple periods of deformation and metamorphic overprint, which occurred during the Proterozoic, Ordovician, Variscan, Late Cretaceous and Cenozoic (Steck, 1968; Labhart, 1977; Schaltegger, 1993; Schaltegger et al., 2003). In our study area (Fig. 1) and further to the west, the EZ is separated from the ILZ by this wedge of Mesozoic sedimentary rocks (Krayenbuhl and Steck, 2009; Herwegh and Pfiffner, 2005; Steck, 1968). Additional autochthonous Mesozoic sedimentary cover rocks are present at the NW rim of the Aar Massif (Kammer, 1989), where they form an own detached and transported nappe system (Doldenhorn nappe; Herwegh and Pfiffner, 2005; Burkhardt, 1988).

The sediment wedges and the Mesozoic cover were only affected by deformation and metamorphism of Alpine age. In the study area, the Alpine metamorphic overprint occurred under lower greenschist metamorphic conditions (Frey and Mählmann, 1999; Niggli and Niggli, 1965), which is recorded by the occurrence of distinct metamorphic index minerals and illite crystallinity. The peak metamorphic temperatures increased towards the SE, where conditions of $\sim 450^{\circ} \mathrm{C}$ and $6.5 \mathrm{kbar}$ have been reconstructed for the central Aar Massif granitoid shear zones (Challandes et al., 2008) at a time around $20 \mathrm{Ma}$ (Wehrens et al., 2017; Herwegh et al., 2017).

\subsection{Alpine structural evolution}

The structural imprint of this ECM has been related to various deformation stages by multiple authors (Table 1), often depending on site-specific conditions. This resulted in the generally accepted notion that during the late Eocene, the Helvetic sedimentary nappes were detached from their crystalline substratum situated further to the SE (Pfiffner, 2014; Herwegh and Pfiffner, 2005; Burkhard, 1988). This process appears not to be recorded by the structural fabric in Aar Massif's basement (Wehrens et al., 2017; Berger et al., 
Table 1. Compilation of deformation phases from literature.

\begin{tabular}{|c|c|c|c|c|c|}
\hline Age (Ma) & Main phase & Substage & Domain & Main characteristics & References \\
\hline $30-22$ & Kiental & & West Helvetics & Nappe stacking with folding & Burkhard (1988) \\
\hline $20-?$ & Grindelwald & & Central Helvetics & Passive rotation and folding & $\begin{array}{l}\text { Burkhard (1988), } \\
\text { Pfiffner (2014) }\end{array}$ \\
\hline $22->12$ & & Handegg & Aar Massif & Steep normal/reverse faults & $\begin{array}{l}\text { Wehrens et al. (2016), } \\
\text { Berger et al. (2017a) }\end{array}$ \\
\hline$<12$ & & Oberaar & South Aar Massif & Dextral/oblique strike-slip faults & Wehrens et al. (2016) \\
\hline$<12$ & & Pfaffenchopf & NW Aar Massif & Flat reverse/normal faults & Wehrens et al. (2017) \\
\hline$<5 ?$ & & Gadmen & NW Aar Massif & Steep brittle reverse faults & Berger et al. (2017a) \\
\hline
\end{tabular}

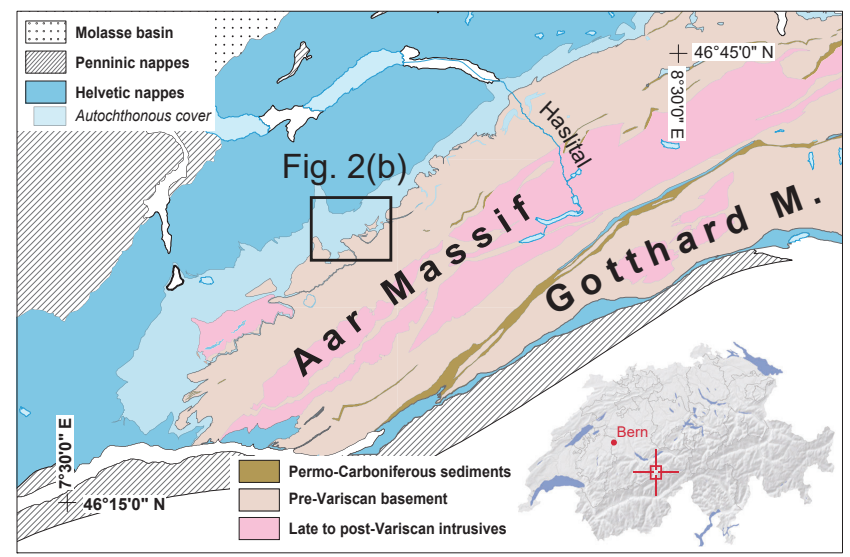

Figure 1. Regional tectonic overview map (modified from Pfiffner et al., 2011) with location of the study area within the Swiss Alps (insert).

2017a). This has been used to disconnect the evolution of the basement rocks from that of the Helvetic cover nappes (e.g., Pfiffner, 2014). An early phase of NW-directed Helvetic thrusting, the Plaine Morte phase of deformation, is recorded in the western Central Helvetic units only (Burkhard, 1988; Pfiffner, 2014). The subsequent Oligocene phases of deformation, which were referred to as the Prabé phase in the west and Calanda phase (Milnes and Pfiffner, 1977) in the east of the Helvetic nappes (Burkhard, 1988; Pfiffner, 2014), were associated with the main phase of top- to NW-dominated thrusting within the Helvetic units, and they are recorded by a penetrative foliation. Further shortening led to the formation of the Doldenhorn nappe (formerly Infrahelvetic and now Lower Helvetic), when a former half graben basin was inverted and incorporated into the Alpine edifice. This phase of deformation, which has been referred to as the Kiental phase (Herwegh and Pfiffner, 2005; Burkhard, 1988), produced a large-scale recumbent fold (Doldenhorn fold sensu stricto) and likewise induced a period of passive folding in the overlying Helvetic nappes. By the end of this phase, at around $20 \mathrm{Ma}$, the Helvetic nappes (Upper Helvetics) existed in positions in front and on top of the future Aar Massif with an inverted stratigraphic succession, where the autochthonous cover and the Doldenhorn nappe (Lower Helvetic) were situated below these nappes (Herwegh and Pfiffner, 2005).

The exhumation history of the crystalline basement rocks of the western Aar Massif, generalized as Grindelwald phase (Burkhard, 1988), records the following multistage lateAlpine deformation sequence: (i) first, steeply south-dipping reverse and normal faults developed a set of pervasive shear zones during the Handegg deformation (Wehrens et al., 2016, 2017), with a progressively increasing uplift component towards the south (Herwegh et al., 2017). This was followed by a phase of strain partitioning with (ii) dextral strike-slip to oblique-slip shearing along NW-SE- and WNW-WSEtrending faults (Oberaar phase) in the south and (iii) simultaneous NW-directed thrusting (Pfaffenchopf phase) along moderately SE-dipping fault planes in the north (Labhart, 1966; Wehrens et al., 2016, 2017; Herwegh et al., 2017; Berger et al., 2017a). During this latter deformation phase, the former main thrust faults and foliation of the Helvetic and Doldenhorn nappes were passively rotated (Burkhard, 1988). This was inferred to have resulted in the present, almost vertical orientation of the main Helvetic thrust in front of the Eiger (Pfiffner, 2014). The latest deformation stage ("Gadmen" phase) is recorded by steep, NE-SW-trending brittle deformation structures with northern block upward movement, which are characterized by mostly steep, cataclastic reverse and normal faults with centimeter-sized offsets (Labhart, 1966; Berger et al., 2017a).

\section{Methods and data}

A regional structural map was produced (Fig. 2) with the aid of remote-sensing techniques. This map was constructed by compiling geological and structural information from previous maps (for a review of the datasets used, see Appendix A). These were verified and updated by own mapping in the field. Special focus was directed towards the mapping of stratigraphic contacts in the sedimentary cover rocks and of shear zones in the basement, both on outcrop and regional scales. We employed high-resolution orthophotos (raster resolution $0.25 \times 0.25 \mathrm{~m}$; provided by swisstopo) and a high-resolution 


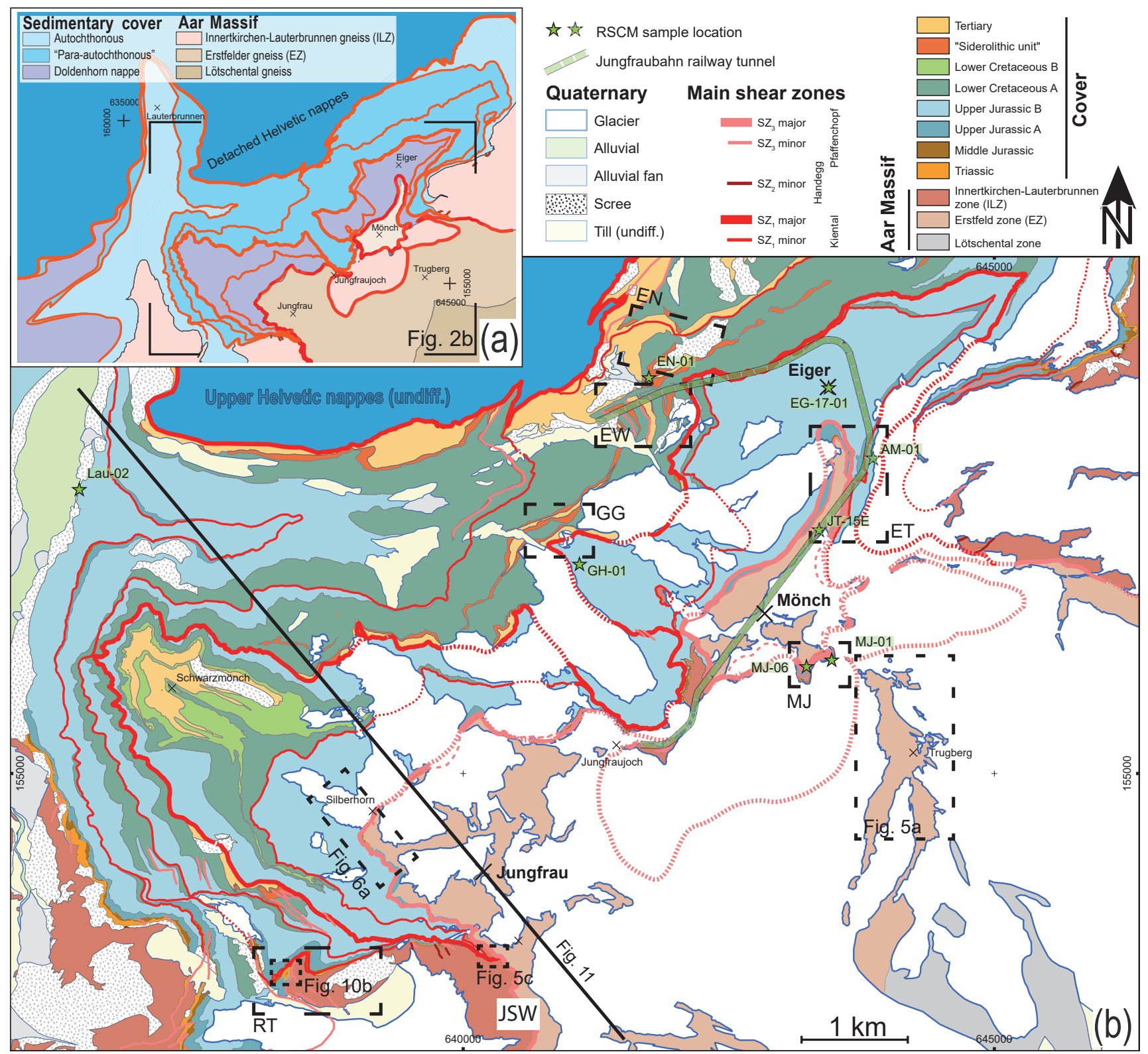

Figure 2. Structural main shear zone map based on own field work and compiled from sources as discussed in Appendix A. (a) Tectonic overview of the studied area. (b) Refined structural and lithological map. Profile trace for Fig. 11 and key locations (EN: Eiger north, GG: Guggi glacier, ET: Eismeer/tunnel, EW: Eiger west, MJ: Mönchsjoch, RT: Rottal, TB: Trugberg; JSW: Jungfrau sediment wedge) are indicated. RSCM sample locations are shown (subsurface samples from the railway tunnel are indicated with dashed stars). Coordinates are given in Swiss coordinates (CH1903).

digital elevation model (swiss ALTI3D, version 2013 provided by swisstopo) as basis for mapping. Structural data (orientation of bedding, lithological contacts, foliation, lineation and faults) were collected with a traditional geological compass and a handheld GPS. The structural dataset was expanded by producing a lineament map, i.e., fault-induced morphological incisions, thereby following the workflow of Baumberger (2015), Baumberger et al. (2018) and Schneeberger et al. (2017), which in turn is based on Rahiman and
Pettinga (2008). We only mapped lineaments that were visible both on the digital elevation model (DEM) and aerial images, and that were readily identifiable in the field. Lineaments that were observed on remotely sensed datasets are indicated as "inferred". Orientations thereof were obtained by plane fitting through moment of inertia analysis of georeferenced point data using the method of Fernández (2005). In addition, we completed the geologic map through collection of geologic information in the Jungfraubahn railway tunnel. 
The tunnel runs oblique to parallel to the striking direction of the main structural elements between $\sim 3000 \mathrm{~m}$ elevation in the east and $\sim 3400 \mathrm{~m}$ in the west (Fig. 2).

The map was combined with microstructural observations on thin sections. Thin sections were cut parallel to stretching lineation and normal to foliation planes, thus allowing shear sense directions to be identified. In addition, we used thin section observations to qualitatively estimate the temperature during peak metamorphic conditions and during periods of dynamic recrystallization of quartz and calcite aggregates.

RSCM was used for peak temperature estimations recorded by the Mesozoic sedimentary rocks. The RSCM technique quantifies the degree of graphitization in metasediments, which is a reliable indicator of peak metamorphic temperature (Beyssac et al., 2002). RSCM measurements were performed with a Jobin Yvon LabRAM-HR800 instrument at the Institute for Geological Sciences at the University of Bern. An Nd:YAG continuous-wave laser $(20 \mathrm{~mW}$ beam spot of $1 \mu \mathrm{m}$ diameter and wavelength of $532.12 \mathrm{~nm}$ ) focused through an Olympus BX41 100x confocal microscope was used. The acquisition of the Raman spectra was monitored with the Labspec 4.14 software of Jobin Yvon. Curve fitting (for histograms, see Appendix B) and temperature estimation followed strictly the procedure described in Lünsdorf et al. $(2014,2017)$ and Lünsdorf and Lünsdorf (2016). The absolute temperature calibration-based error is on the order of $\pm 40^{\circ} \mathrm{C}$; however, relative temperature differences can be resolved down to $\pm 15^{\circ} \mathrm{C}$ (Lünsdorf et al., 2017; Nibourel et al., 2018).

\section{Results and interpretation}

We present an inventory of structural rock fabrics (both on outcrop and microscale) of the studied area. These fabrics developed during Alpine deformation and are different for the sedimentary cover rocks and for the basement lithologies.

\subsection{Host rock characteristics}

\subsubsection{Polymetamorphic Aar Massif basement rocks (ILZ and EZ)}

The basement rocks of the ILZ and the EZ consist of plagioclase, alkali feldspar and quartz-dominated gneisses, which are occasionally enriched in micas (mainly biotite and white micas) and chlorite minerals (Fig. 3b). In the study area, the texture ranges from typical coarse-grained granoblastic (the largest grain size of feldspars is $<2 \mathrm{~cm}$ ) to fine-grained granoblastic (grain sizes of $\ll 1 \mathrm{~mm}$ ) for the matrix zones of the migmatites (Rutishauser, 1973). Usually the feldspars (both alkali feldspar and plagioclase), together with biotite, form large grains with interstitial quartz. This texture is only partially preserved due to a later greenschist facies overprint.
This overprint is recorded by chlorite replacing biotite and quartz, sericitization of feldspar grains, as well as by the growth of interstitial white mica (Berger et al., 2017b). The overprint, however, did not completely erase the original high temperature fabric; instead, it often forms core-rim structures around altered feldspar grains (Fig. 3b). Quartz aggregates still preserve the original texture. No new biotite growth occurred, and no preferred orientation, neither for quartz nor micas, on the microscale is found. This aligns well with the lack of evidence for an Alpine foliation on the outcrop scale in some basement rock outcrops outside discrete shear zones.

\subsubsection{Mesozoic sedimentary cover rocks}

The Mesozoic strata form an originally up to $500 \mathrm{~m}$ thick succession of limestones, mudstones and sandstones (Fig. 4; for detailed discussion, see Appendix A). The stratigraphic suite can be synthesized into eight larger units (Fig. 4 and Table 2). This allows to distinguish the main stratigraphic horizons and to group units with similar mechanical strengths (see also Pfiffner, 1993; Sala et al., 2014). These units comprise the Triassic (Mels Fm., Quarten Fm. and Röti Fm.), the Middle Jurassic (Bommerstein Fm. and Reischiben Fm.; "Dogger"), the Upper Jurassic A (Schilt Fm.) and B (Quinten Fm.), the Lower Cretaceous A (Öhrli Fm.) and B ("Helv. Kieselkalk" and Betlis Fm.), the siderolithic and the Tertiary units.

There are several main characteristics needed to understand the structural fabrics within the individual sedimentary units. The basal Triassic, above the weathered basement cover contact, is formed by crystallized cellular dolomites and shales (Appendix Fig. A1). Despite varying thicknesses $(5-50 \mathrm{~m})$ and lithologic characteristics, it is present throughout the entire study area. The 250 to $300 \mathrm{~m}$ thick suite of Upper Jurassic limestones and the overlying up to $150 \mathrm{~m}$ thick succession of Lower Cretaceous limestones form the bulk of the strata and are constant in thickness throughout the studied area. The only difference between the facies domains (Fig. 4; aside from thicker Lower and Middle Jurassic strata) is the presence of a Cretaceous B unit (in the northern flanks of Jungfrau and Eiger), which consists of layered cherts with limestone interbeds. Note that these features allow its identification as continuation of the Doldenhorn nappe further to the west.

\subsection{Deformation structures}

The studied mountain chain is dissected by numerous high strain zones with variable orientations, which occur in the basement and in the sedimentary cover.

\subsubsection{Basement strain localization}

Locally, a weakly developed, pre-Alpine foliation can be found. If preserved, it is usually cut or overprinted by Alpine structures. These latter structures generally occur as discrete sub-millimeter- to meter-thick shear zones in the field 

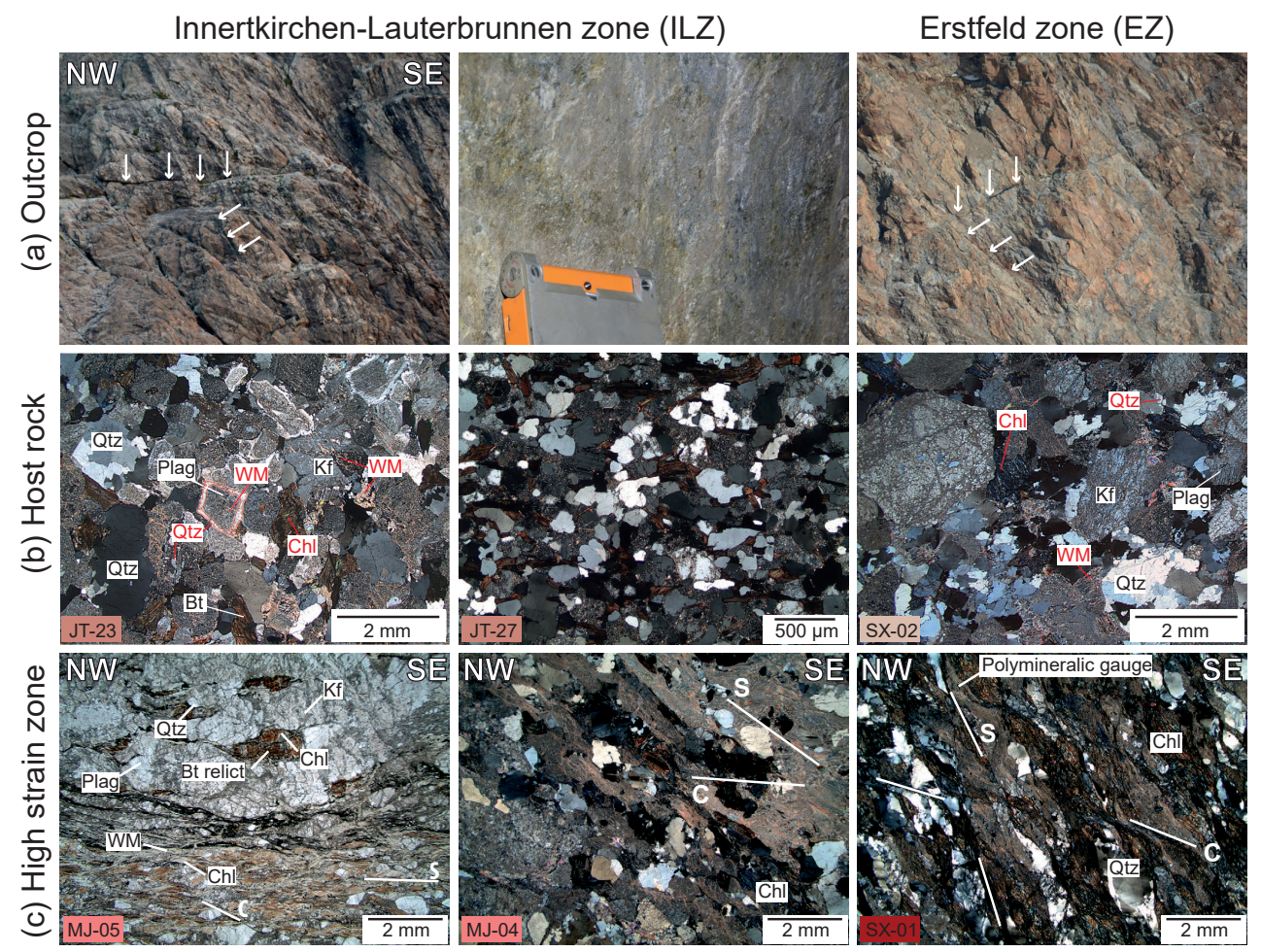

Figure 3. Key basement rock fabrics. (a) Outcrop images with indication of discrete shear zones (white arrows). (b) Crossed polarized light micrographs of pre-Alpine fabrics with relict granoblastic microstructures of large feldspar and biotite crystals, and interstitial quartz. Metamorphic overprint manifests in (i) white mica and quartz growth with smaller grain sizes, (ii) the alteration rims of feldspar and (iii) biotite to chlorite alteration (minerals from overprint are marked in red). Note the highlighted core-rim structure stemming from feldspar sericitization. (c) Shear zone micrographs. SC: fabrics are formed by white mica, chlorite and polymineralic fine-grained ultracataclasite or ultramylonite in between porphyroclasts (which exhibit brittle deformation). Mineral abbreviations - Bt: biotite, Chl: chlorite, Kf: alkali feldspar, Plag: plagioclase, Qtz: quartz, WM: white mica. Sample names are indicated; for sample details, see Table A1.

Table 2. Key stratigraphic horizons with most important features and references (for a detailed discussion, see Appendix A). NA - not available.

\begin{tabular}{|c|c|c|c|c|c|}
\hline Simplified layer & Fm. name & Age & Lithology & References & Thickness \\
\hline \multirow[t]{2}{*}{ Tertiary } & Stad Fm. & Priabonian & shales intercalated with sandy layers/lenses & $\begin{array}{l}\text { Herb (1983), Menkveld-Gfeller et } \\
\text { al. (2016) }\end{array}$ & NA \\
\hline & Niederhorn Fm. & $\begin{array}{l}\text { Bartonian - } \\
\text { Priabonian }\end{array}$ & $\begin{array}{l}\text { shallow marine limestones, intercalated with } \\
\text { sandstones }\end{array}$ & $\begin{array}{l}\text { Herb (1983), Menkveld-Gfeller et } \\
\text { al. (2016) }\end{array}$ & NA \\
\hline Siderolithic & Siderolithic & $\begin{array}{l}\text { Lutetian - } \\
\text { Bartonian }\end{array}$ & $\begin{array}{l}\text { erosional infill in karst pockets (sandstones, } \\
\text { iron-rich carbonates) and calcareous breccia }\end{array}$ & Menkveld-Gfeller et al. (2016) & $<10$ to $40 \mathrm{~m}$ \\
\hline Lower Cretaceous B & $\begin{array}{l}\text { Betlis Fm./ Helv. } \\
\text { Kieselkalk (?) }\end{array}$ & Valanginian & $\begin{array}{l}\text { brown weathering biogene spary limestone with } \\
\text { chert layers and sandy layers in the top }\end{array}$ & Strasser (1982), this study & 50 to $90 \mathrm{~m}$ \\
\hline Lower Cretaceous A & Öhrli Fm. & Berriasian & light grey, oolithic - biogene limestones & Collet and Paréjas (1931) & ? to $150 \mathrm{~m}$ \\
\hline Upper Jurassic B & Quinten Fm. & $\begin{array}{l}\text { Oxfordian - } \\
\text { Berriasian }\end{array}$ & $\begin{array}{l}\text { dark, micritic limestones; on top reef platform } \\
\text { limestones }\end{array}$ & $\begin{array}{l}\text { Collet and Paréjas (1931), Masson } \\
\text { et al. (1980) }\end{array}$ & 150 to $250 \mathrm{~m}$ \\
\hline Upper Jurassic A & Schilt Fm. & $\begin{array}{l}\text { Callovian - } \\
\text { Oxfordian }\end{array}$ & intercalated limestones with thin marly layers & Masson et al. (1980) & 10 to $50 \mathrm{~m}$ \\
\hline \multirow[t]{2}{*}{ Middle Jurassic } & Reischiben Fm. & $\begin{array}{l}\text { Aalenian - } \\
\text { Bathonian }\end{array}$ & $\begin{array}{l}\text { echinodermata-bearing calcareous breccia and } \\
\text { iron bearing sandstones }\end{array}$ & Bruderer (1924) & $<1$ to $10 \mathrm{~m}$ \\
\hline & Bommerstein Fm. & $\begin{array}{l}\text { Toarcian - } \\
\text { Aalenian }\end{array}$ & $\begin{array}{l}\text { shales with intercalated iron-rich sandstones and } \\
\text { echinodermata-bearing calcareous breccia }\end{array}$ & Bruderer (1924) & $<1$ to $30 \mathrm{~m}$ \\
\hline \multirow[t]{3}{*}{ Triassic } & Quarten Fm. & Late Triassic & dolomites and shales & Bruderer (1924), this study & NA \\
\hline & Röti Fm. & Anisian & $\begin{array}{l}\text { dolomites: pseudomorphs after gypsum, oolithic } \\
\text { grainstones and mudstones; well-bedded }\end{array}$ & $\begin{array}{l}\text { Gisler et al. (2007), Collet and Paré- } \\
\text { jas (1931), Rohr (1926) }\end{array}$ & 5 to $25 \mathrm{~m}$ \\
\hline & Mels Fm. & $\begin{array}{l}\text { Olenekian - } \\
\text { Anisian }\end{array}$ & $\begin{array}{l}\text { intercalated sandstones, clays and dolomites } \\
\text { (partly gypsum bearing) }\end{array}$ & $\begin{array}{l}\text { Gisler et al. (2007), Rohr (1926), } \\
\text { this study }\end{array}$ & $<10 \mathrm{~m}$ \\
\hline NA & NA & Permian? & regolith (weathered Permian basement rock) & this study & $<5 \mathrm{~m}$ \\
\hline
\end{tabular}




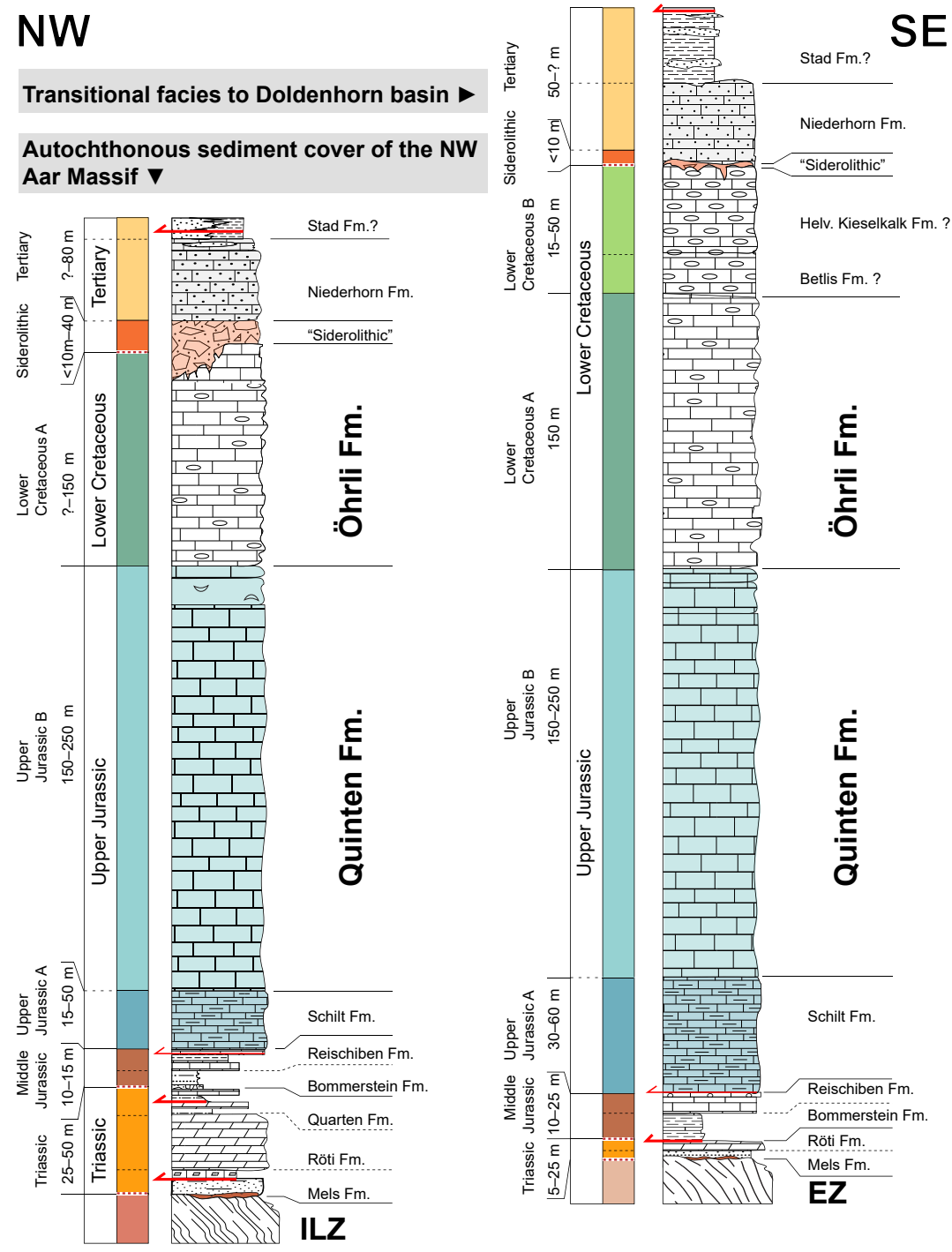

Figure 4. Detailed stratigraphic profiles for the Mesozoic sedimentary cover (for sedimentological discussion, see Appendix A). Future main detachment horizons are marked (red arrows) - ILZ: Innertkirchen-Lauterbrunnen zone, EZ: Erstfeld zone. For references for the thickness estimates and individual unit names, see Table 2.

(Fig. 5a). They are present either as a set of generally steep south-dipping or as a set of intermediate south-dipping semibrittle to brittle faults, both forming on former shear zones (Fig. 5). These steep faults on reactivated shear zones, which we define as SZ2 (Figs. 3 and 6; note that SZ1 shear zones were only found in the sedimentary rocks), exhibit normal and reverse kinematics with dominantly top to the NW shear senses, as is indicated by the offset of older structures (Fig. 5b, c) and by dip-slip stretching lineation (Fig. 6a). Several individual faults show evidence for reverse movements as documented by displacements of isolated decimeter-sized blocks. Typical Riedel shears are present, highlighting the conjugate semi-brittle nature of the shear zones. The spacing between them decreases towards the NW and close to the JSW. In the Rottal (RT), the mean orientation of these structures is $315 / 84$ (dip azimuth/dip) with indications for up movements of the southern blocks. In the Trugberg (TB) zone, the average dip azimuth is 180/52 (inferred from remote sensing). Note that, due to younger deformation overprint, the original orientation might have been different than at present.

An intermediately steep set of shear zones (SZ3; Fig. 6) cuts and offsets the SZ2 structures. The spacing of the shear zones is on the order of tens of meters and therefore much wider compared to the centimeter-to-meter spacing of SZ2. In addition, the SZ3 deformation is more localized (especially within the JSW; Fig. 5). The orientation of the SZ3 suites also changes from moderately steep SEdipping to NW-dipping orientation in the NW (TB: 157/22 vs. RT: 351/27) with NW-plunging stretching lineations (RT: 

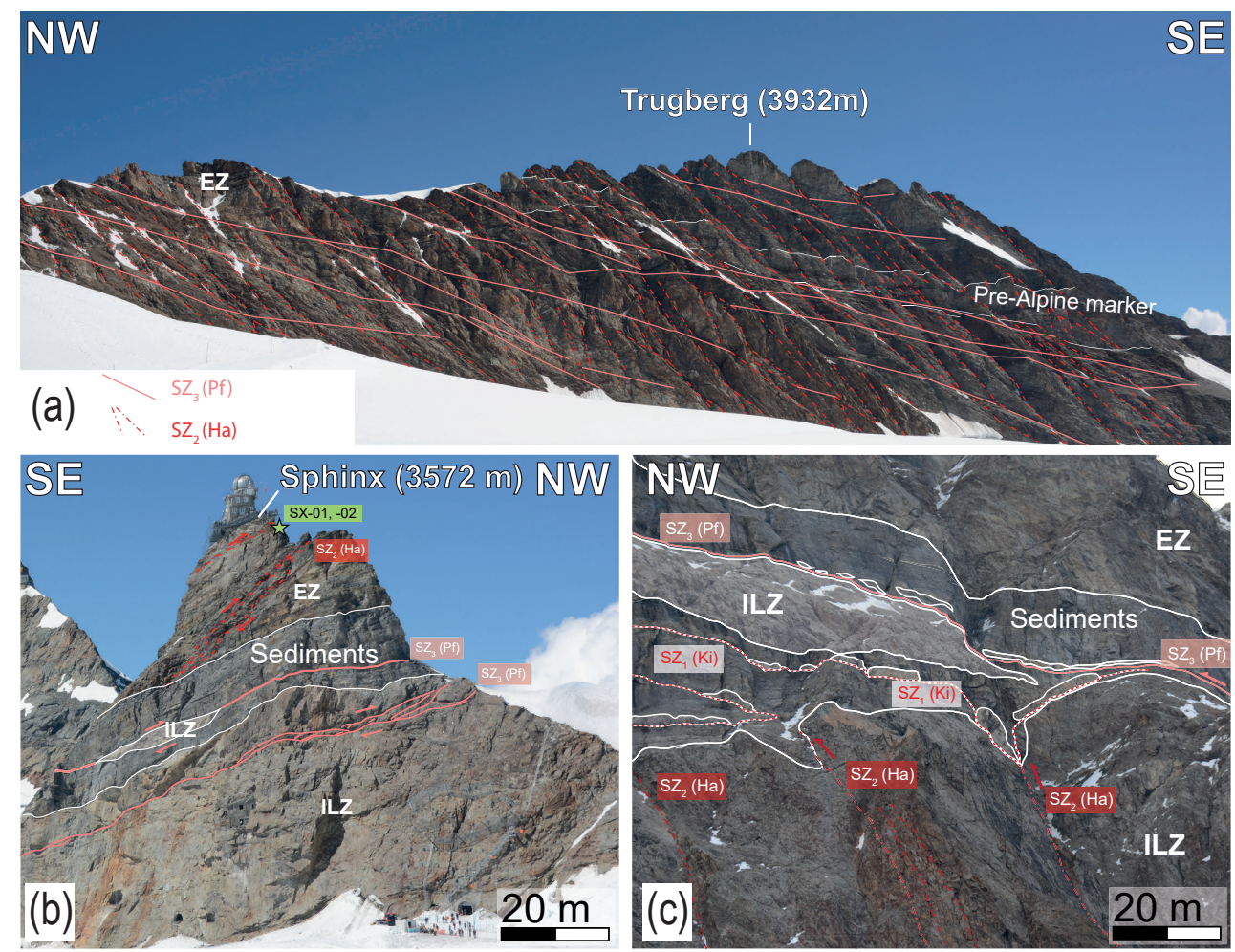

Figure 5. Deformation structures in the basement on the large scale in different key outcrops along the strike of the mountain chain (localities are indicated in Fig. 2). (a) Trugberg mountain ridge viewed from the west: the complex shear zone network with indication of the individual deformation-phase structures Pf: Pfaffenchopf phase, Ha: Handegg phase (see also Fig. 6). (b) The Jungfrau sediment wedge (JSW) from the east with an incorporated large basement wedge that separates the Innertkirchen-Lauterbrunnen zone (ILZ) from the Erstfeld zone (EZ). (c) Late stage shear zoning below the Jungfrau demonstrating the complex cross-cutting and overprinting relationship of the different structures (Ki: Kiental phase). For deformation phase discussion and attribution, see discussion in text. Location of key samples is indicated (SX-01, SX-02).
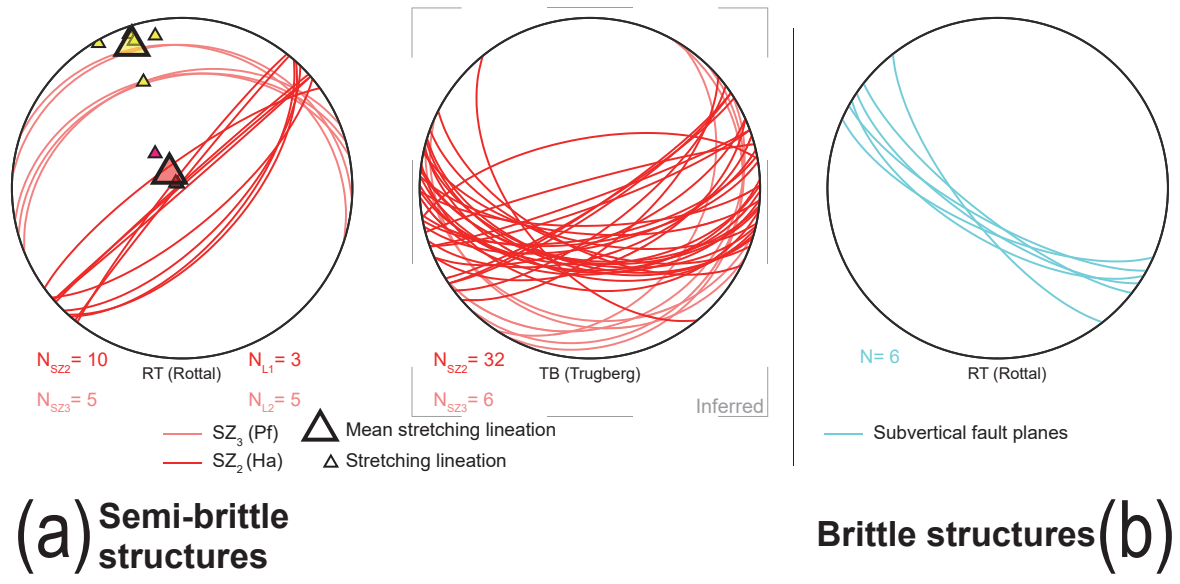

Figure 6. Structural field data for the basement from the Rottal (RT) and Trugberg (TB). (a) Shear zones related to main phases of exhumation. Shear zone orientations for TB were inferred by plane fitting through the moment of inertia of remote-sensed lineaments (data provided in the Supplement folder S1). (b) Vertical lineaments that cross-cut structures as shown in panel (a). For geographical abbreviations and shear zone legend, see Fig. 2. 
322/21). The shear sense of SZ3 is characterized by top-toNW thrusting (Figs. 6a, 9).

Despite the differences in orientation and kinematics, the microfabrics of both SZ2 and SZ3 samples show no difference in terms of deformation microstructures and mineral assemblages. Grains of the original pre-Alpine granoblastic fabric are either replaced by new grains of much smaller size (i.e., chlorite, white mica, epidote; Fig. 3c) or they experienced mechanical grain size reduction down to a few micrometers. These small-grained minerals are often concentrated in micrometer- to centimeter-thick polymineralic bands. They form S-C fabrics and shear bands (Fig. 3). However, feldspar and quartz minerals are still present as porphyroclasts despite evidence for incipient dynamic bulging recrystallization for quartz (see also Bambauer et al., 2009). Notable is the higher phyllosilicate content in shear zone rocks compared to the host rock composition.

The youngest set of (i) SE-NW-striking steep faults (F1) and (ii) NW-SE-oriented, subvertical fault planes (F2) cut all older structures (Figs. 6c, 9b) and are characterized by brittle deformation forming cataclasites, fault breccias and gauges (Appendix Fig. A2). Both fault sets cross-cut all other structures and are best detected in the subsurface (along the Jungfraubahn tunnel; Fig. 2), due to their susceptibility to weathering. Set F1 mainly features millimeter- to centimeterwide fault zones along a set of open joints. However, the offset of these faults is on the order of a few centimeters to meters and is thus not resolvable at the scale of Figs. 2 and 10. Set F2 shows oblique to strike-slip kinematics (Appendix Fig. A2) in centimeter- to meter-wide cataclastic shear zones, often with fault gauges at the core.

\subsubsection{Deformation in the sedimentary cover rocks}

The sedimentary rocks show strong evidence for ductile deformation and brittle deformation, both on outcrop scale and in thin sections. The calcite-dominated limestones exhibit a strong ductile overprint, expressed by complete dynamic recrystallization of the original fabric with grains that are smaller than $25 \mu \mathrm{m}$ (Fig. 8). They show a well-developed foliation (S1) parallel to the bedding in most of the study area, which formed through abundant calcite dissolution and dynamic recrystallization. This first mylonitic fabric (S1) shows a foliation spacing ranging from several centimeters in the lower RT (Rottal) section to $\ll 1 \mathrm{~mm}$ in the Mönchsjoch (MJ). Typically, it overprints the bedding completely (Fig. 7). Notably, the Triassic dolomite (Röti Fm.) was not deformed in a ductile but rather in a brittle or semi-brittle manner. This is expressed in abundant bookshelf structures and dominolike boudins (Fig. 7c) affected by more than one deformation phase. These rigid lenses are stretched out along shear planes or form kink folds near the basement cover interface (Fig. 1). The same applies to Middle Jurassic iron-rich sandstones and Cenozoic iron-rich sandstones or iron-carbonate nodules (Siderolithic). This deformation style leads to macroscopic- (and microscopic-) scale boudins (Figs. 7 and 8), thereby making these units ideal stratigraphic markers to identify shear zones and stratigraphic polarity (Fig. 2).

In the NW flank of the Jungfrau-Eiger mountains, the Mesozoic strata are segmented in distinct stacks, separated by arrays of discrete shear zones (SZ1) of $<1 \mathrm{~m}$ to up to $5 \mathrm{~m}$ widths that are generally aligned parallel to the $\mathrm{S} 1$ foliation where the layer spacing decreases towards the shear zones. These shear zones acted as thrusts with a general top-toNW displacement direction. They were accompanied by the circulation of metamorphic fluids, as testified by abundant iron-rich, micrometer-thick layers of precipitated minerals. Growth of white mica and chlorite minerals within the pressure shadows is frequently observed, mainly in non-calcitedominated lithologies. These thrusts contain slivers of ILZ basement rocks of the footwall, which are now incorporated in the sedimentary stacks (e.g., in the Rottal area; Figs. 2, 10).

Subsequent to the SZ1 thrusting, counterclockwise rotation of the initial structures (bedding and S1, in section view, looking east) was accomplished by local folding near the basement cover contact. The folding produced SE-dipping and SW/W- to NE/E-striking axial planes, which locally form an axial plane foliation (S2). This deformation affected the sedimentary rocks in an asymmetric way, where folding became more intense towards the SE, culminating in a decimeter-spaced axial plane foliation (S2) in the JSW (Fig. 7e). As a result, the present-day orientation of $\mathrm{S} 1$ varies from SE dipping (118/35 for region EN, 118/36 for region EW; see Figs. 2 and 9 for locality) in the lower paraautochthonous slice to NW dipping (312/22 for region GG; 297/36 for region EM; Fig. 9).

Subsequent NW-directed shearing led to a further thinning of favorably SE-dipping or flat-lying aligned thrust planes of S1 fabrics in the now flat-lying limbs of the stacked imbricates (Fig. 10). The new foliation (S3) formed often parallel (or only cutting under low angles) to the pre-existing mylonitic foliation (e.g., Fig. 7a, d). In the cases where S1 structures dip steeply to the NW (e.g., in RT region or at the location of Fig. 7b), the local new foliation (S3) developed still under the same orientation, cutting the older foliation (S1) at high angles (Figs. 7b, 10). This foliation features evidence for slip where $\mathrm{S} 1$ fabrics are cut. Dip azimuth alters between gently SE dipping, flat lying and NW dipping, with a dominant top-to-NW sense of shear, indicated by stretching lineation data derived from abundant calcite slickenside striations on S3 slip planes. This shearing occurred still under ductile conditions for calcite. However, non-limestone dominated lithologies, which include basement slivers, exhibit shear localization merely by mechanical grain size reduction of minerals to a few microns. They form a microcrystalline cataclastic fabric consisting mainly of quartz, white mica, chlorite, epidote and feldspar.

The latest deformation stage produced a set of brittle subvertical NW-SE-striking faults (F1) and steep SW-NE- 

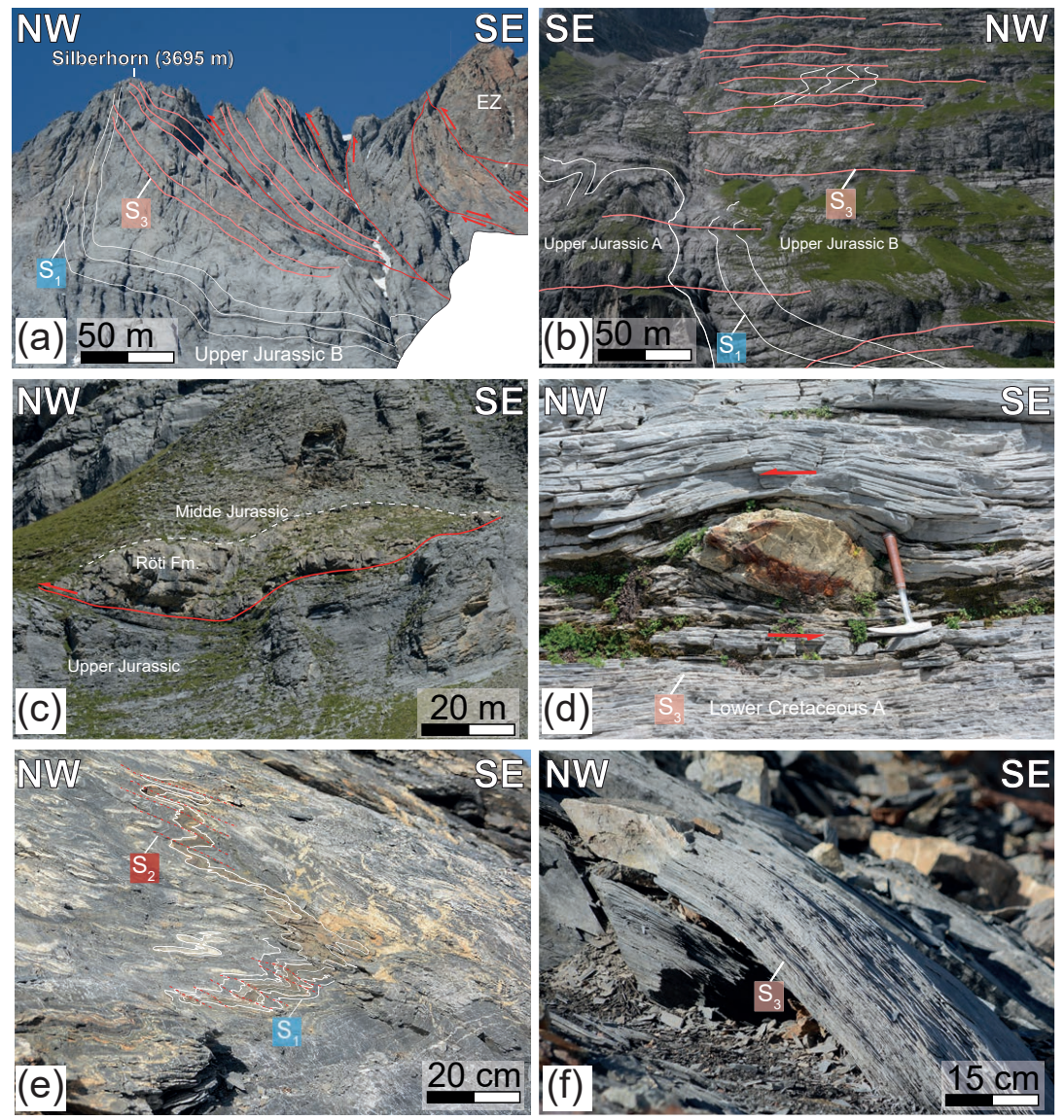

Figure 7. Field examples of key deformation structures within the sedimentary rocks. (a) Modulation of the previous foliation (S1, white lines) by the latest stage fault system (solid red lines) and the contemporarily induced foliation (S3, pink lines) in the summit region of the Jungfrau. (b) Similar overprinting of already folded bedding by the younger foliation east of the Eiger summit in a lower level (elevation around $2500 \mathrm{~m}$ a.s.1). (c) Decameter-sized dolomite boudin of the Triassic (Röti Fm.) marking the shear zone at its base in the RT (Rottal) region, which is the roof thrust of the autochthonous cover unit. (d) Decimeter-sized sigma clast of boudinaged iron-rich nodules (siderolithic unit) within the ductile host rock mylonites that marks a shear zone in the west flank of the Eiger mountain. (e) Local modulation of the initial foliation and folds by steep SE-plunging axial planes with foliation, inflicted during the intermediate step of deformation (Ha). (f) Carbonaceous ultramylonite in the MJ transect, some decameters above the location of panel (e), showing the strongly localized, latest overprint, completely transposing traces of previous deformation.

striking oblique oriented brittle faults with evidence for strike-slip and reverse/normal fault behavior (F2). Both are found within basement and cover rocks of all levels (documented by fault breccia and mineralized veins cross-cutting an older set; Appendix Fig. A2). These overprint all other structures. Due to the brittle nature and connection to the surface, they are often water saturated and highly susceptible to weathering. Despite cutting across all units, offsets (if even present) are limited to a few centimeters only and are thus not visible on map scale.

\subsection{Peak metamorphic temperature}

RSCM was used on eight selected samples representing the different tectonic levels in the studied area to constrain peak Alpine metamorphic temperatures for the sedi- mentary cover (Table 3). Results yield the lowest temperatures for the presently lowest elevation sample (LAU-02: $283 \pm 14{ }^{\circ} \mathrm{C}$ at $838 \mathrm{~m}$ a.s.l. for the Upper Jurassic limestone) and samples from the Eiger north flank (EN-01: $283 \pm 12^{\circ} \mathrm{C}$ at $2388 \mathrm{~m}$ a.s.1.). Slightly higher peak temperatures are obtained for samples collected at the Eiger summit (EG-1701: $292 \pm 10^{\circ} \mathrm{C}$ at $3970 \mathrm{~m}$ a.s.l.). Highest temperatures are found in the JSW samples (MJ-03 and MJ-06: $308 \pm 14$ and $317 \pm 11^{\circ} \mathrm{C}$, respectively). The data indicate a trend to slightly higher temperatures towards the more internal units in the SE. We employ a constant average geothermal gradient of $27^{\circ} \mathrm{C} \mathrm{km}^{-1}$ (Schlunegger and Willett, 1999; Glotzbach et al., 2010; Valla et al., 2016), falling in the global range for the upper continental crust for the past (Pollack and Chapman, 1977). Thus, we are able to reconstruct the approximate minimum sample depth at peak metamorphic condi- 


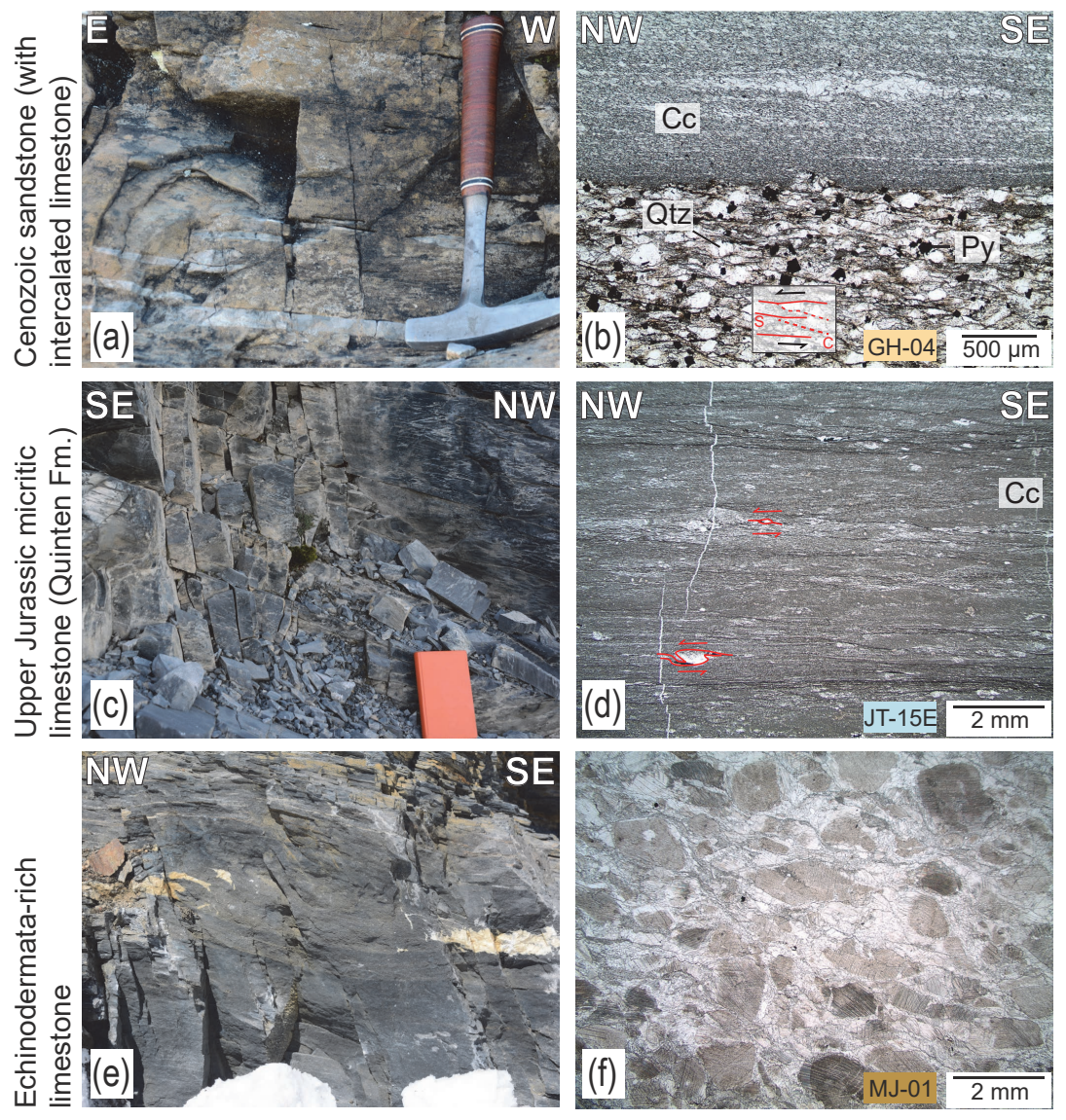

Figure 8. Deformation structures on outcrop and microscale. (a) Ultra-mylonitic Tertiary sandstones intercalated with calcite limestones that (b) show a dynamically recrystallized fabric in the limestone part, while the quartz within the S-C mylonite exhibits still (semi-) brittle behavior. This manifests in mylonitic ductile shear bands formed by micas and calcite while quartz grains (along with pyrite) form sigmoidal clasts. (c) Dark micritic limestone mylonites of the Upper Jurassic B unit with a (d) completely recrystallized fabric of microcrystalline calcite. (e) Echinodermata-rich limestone of the Middle Jurassic show the low $P, T$ overprint with (f) undeformed echinodermata, probably due to consisting of magnesium calcite, which makes these minerals stronger (Xu et al., 2009). Mineral abbreviations: Cc - calcite, Qtz quartz, Py - pyrite.

tions. This allows us to identify the vertical position of the corresponding units relative to each other. The overall temperature range of 283 to $317^{\circ} \mathrm{C}$ indicates a sample depth between 10.5 and $12 \mathrm{~km}$, or even shallower, at peak temperature conditions. This further constrains the peak temperature for the crystalline substratum of these sedimentary rocks to $<330^{\circ} \mathrm{C}$.

\subsection{Imbricate geometry in the sedimentary cover}

Stratigraphic markers (see Sect. 4.1.2) are used to delineate geometrical units separated by thrusts of different generations (see Sect. 4.2.2). From NW to SE (and present-day bottom to top), we find the ILZ and its sedimentary cover still in its original position. This is superimposed by two approximately $500 \mathrm{~m}$ thick imbricate stacks, with normal stratigraphic succession within each stack (often referred to as "para-autochthonous", Fig. 11). On top of these, we addi- tionally find $\mathrm{a}>1000 \mathrm{~m}$ thick pile of Cretaceous and Jurassic limestones, which was often referred to as the core of a syncline (Krayenbuhl and Steck, 2009). These units are deformed as an ensemble during stage 2 and stage 3 phases of deformation as described in Sect. 4.2.2 (see Fig. 10). The subdivision of this sedimentary stack is internally consistent along strike within the study area. Lateral differences in structural style, which occurred in response to the last two deformation stages, are expressed by less shortening along the JSW (as shown in map view; see Fig. 2), while more basement slabs were detached and thrusted at a lower level. The ensemble of this deformation pattern resulted in a locally steeper (almost vertical) orientation of the basement cover contact. This is mainly due to the large differential block uplift in the basement (SZ2) that passively steepened the sedimentary cover in the SE. 

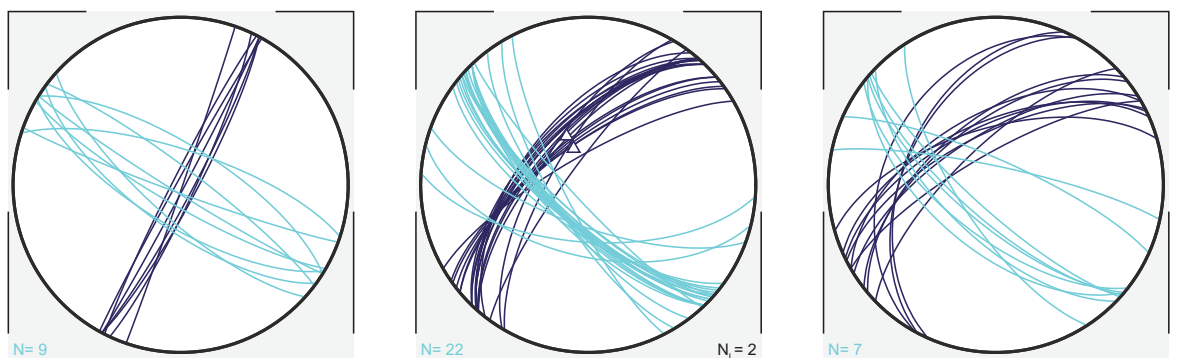

Brittle structures

(b)

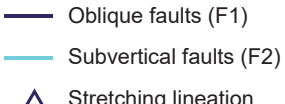

$\Delta$ Stretching lineation
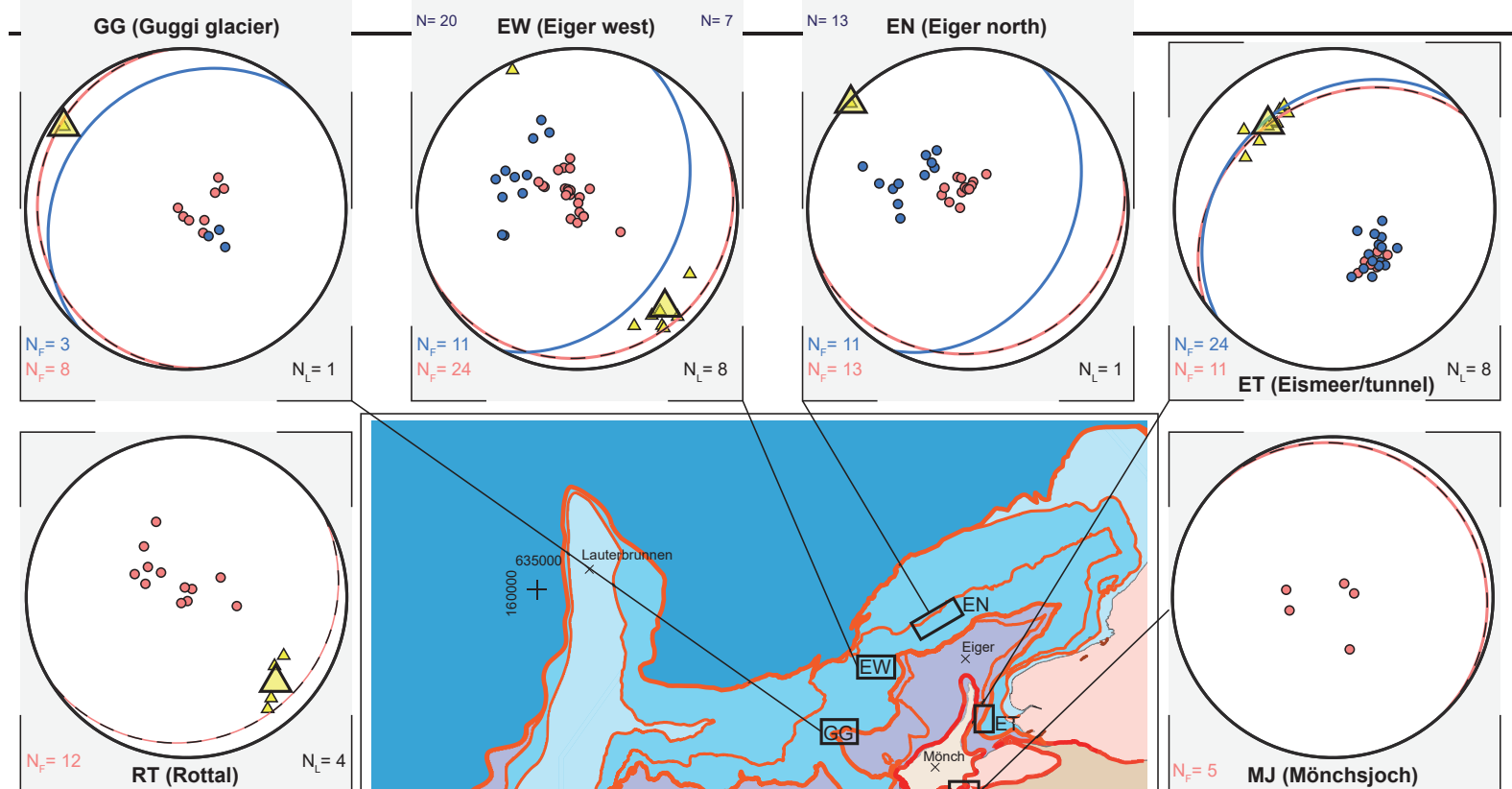

- $S_{1}$ mean (great circle)

- $S_{3}$ mean (great circle)

$\triangle$ Mean stretching lineation

Ductile to semi-brittle structures
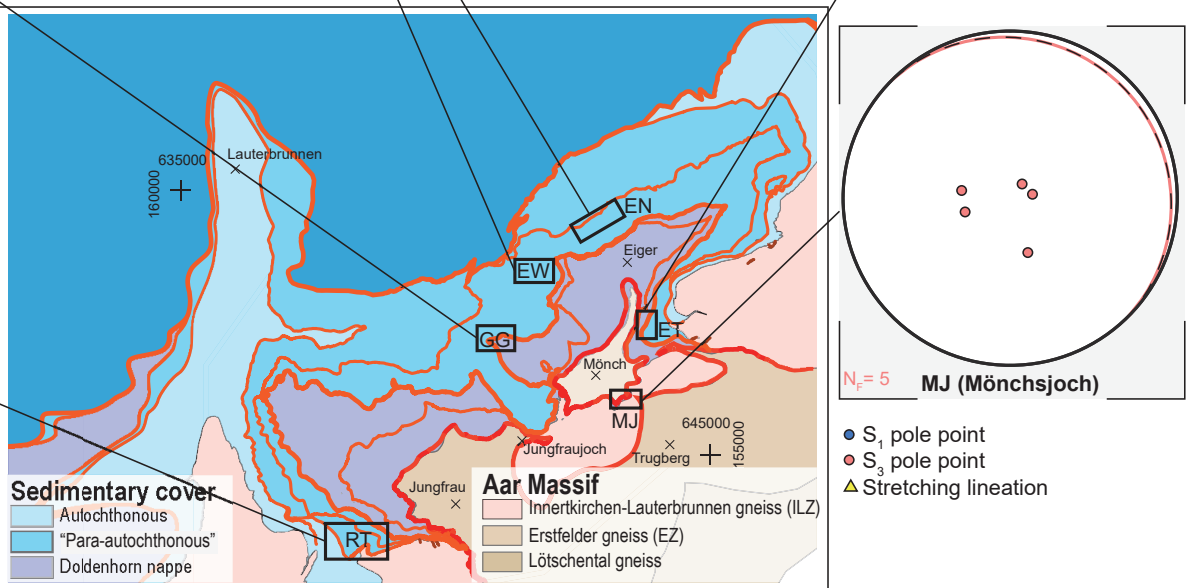

- $S_{1}$ pole point

- $S_{3}$ pole point

$\Delta$ Stretching lineation

Figure 9. Deformation structures in the sediments. (a) Bedding parallel S1 foliation and later induced S3 foliation that consists of numerous slip surfaces. Stretching lineation is only documented on S3 surfaces. (b) Brittle-only structures that cross-cut structures in panel (a).

Table 3. RSCM temperature estimation for peak metamorphic temperature; PA: para-autochthonous sediments, DN: Doldenhorn nappe, AUT: autochthonous sediments. Coordinates are given in the Swiss coordinate system (CH1903).

\begin{tabular}{lrrrllrc}
\hline Sample & $x$ & $y$ & $\begin{array}{r}\text { Elev. } \\
(\mathrm{m})\end{array}$ & $\begin{array}{l}\text { Stratigraphic } \\
\text { unit }\end{array}$ & $\begin{array}{l}\text { Tectonic } \\
\text { unit }\end{array}$ & $\begin{array}{r}\text { RSCM temp. } \\
\left({ }^{\circ} \mathrm{C}\right)\end{array}$ & $2 \sigma$ \\
\hline MJ-01 & 643469 & 156074 & 3649 & Middle Jurassic & JSW & 308 & \pm 14 \\
MJ-06 & 643232 & 156012 & 3744 & Upper Jurassic A & JSW & 317 & \pm 11 \\
EN-01 & 641749 & 158733 & 2388 & Lower Cretaceous A & PA & 283 & \pm 12 \\
LAU-02 & 636387 & 157680 & 838 & Upper Jurassic B & AUT & 283 & \pm 11 \\
EG-17-01 & 643440 & 158638 & 3970 & Upper Jurassic B & DN & 292 & \pm 10 \\
JT-15E & 643351 & 157295 & 3216 & Upper Jurassic B & PA & 287 & \pm 14 \\
AM-01 & 643859 & 157971 & 3127 & Upper Jurassic B & PA & 307 & \pm 19 \\
GH-01 & 641095 & 156976 & 2798 & Upper Jurassic B & DN & 289 & \pm 27 \\
\hline
\end{tabular}



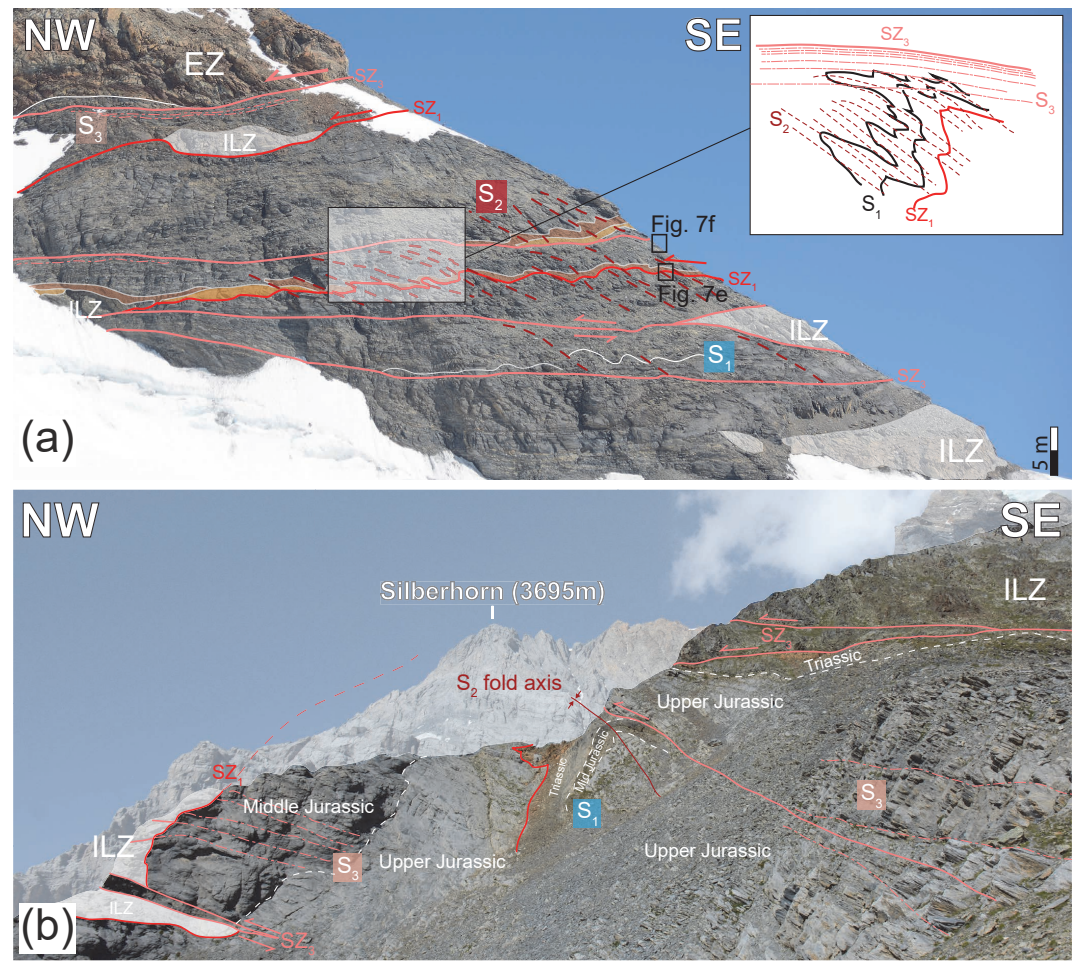

Figure 10. Cross-cutting and overprinting relations between the structures close to the basement cover contact for key locations. (a) Sediments in the Jungfrau sediment wedge (JSW), at the Mönchsjoch locality (MJ; see Figs. 2, 9), between the Erstfeld zone (EZ) and the Innertkirchen-Lauterbrunnen zone (ILZ) illustrating the cross-cutting and overprinting (see also insert). Note that some sediment markers are highlighted (brown: Middle Jurassic, orange: Triassic). (b) Similar structures at the Rottal (RT; see Figs. 2, 9) location, where the late thrusting of the ILZ basement caused deflection and rotation of the S2 folds and cross-cutting and passive rotation of the SZ1 thrusts. Note the penetrative S3 foliation.

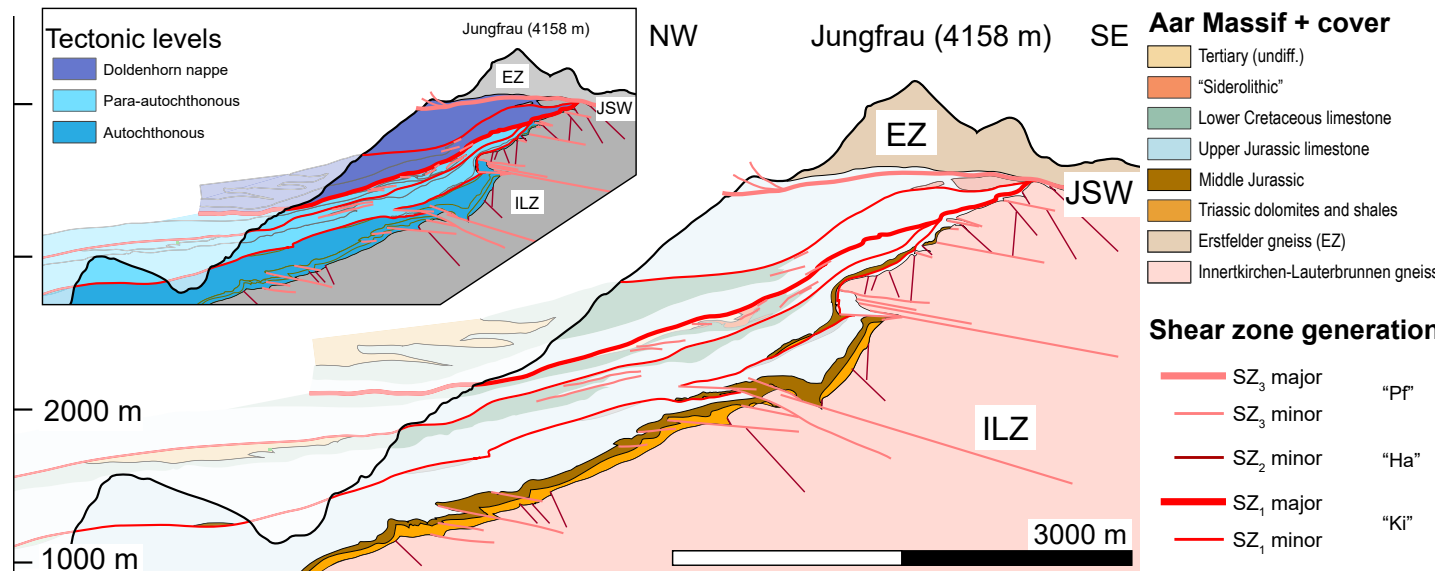

Figure 11. Simplified structural profile across the NW rim of the Aar Massif (profile trace indicated in Fig. 2).

\section{Discussion}

The sedimentary cover reveals a set of distinct deformation fabrics that formed during a three-stage evolution. We derive these stages from aforementioned field data and geometri- cal relationships. By disentangling the fabrics related to each stage, we can link these in a regional geodynamic context. 


\subsection{Pre-Alpine inheritance}

An important role falls to Paleozoic and older structures that are inherited in the basement (i.e., the polymetamorphic basement called Altkristallin in the German literature; Steck, 1968). Since the ILZ and EZ were originally sedimentary protoliths (Rutishauser, 1973, 1974; Schaltegger, 1993), they feature a heterogeneous architecture (i.e., Abrecht, 1994). Large-scale partial melting produced the original host rock fabric (Sect. 4.1.1). Radiometric dating yielded Ordovician ages for the high temperature metamorphic overprint of the EZ ( $456 \pm 2 \mathrm{Ma})$ and the ILZ migmatites ( $452 \pm 5 \mathrm{Ma}$; Schaltegger, 1993). Thus, any evidence of a previous geological history was erased, but the metasomatic overprint preserved to some extent the original heterogenous lithological character (Berger et al., 2017b; Abrecht, 1994). Subsequent tectonic events already aligned structures, i.e., lithological boundaries and foliation (Schaltegger et al., 2003), along a SW-NE direction. The wedging-in of Permian volcaniclastic sediments (Berger et al., 2017b), which was associated with folding, suggests that the basement internal nappe emplacement occurred during the Carboniferous (Oberhänsli et al., 1988). The emplacement of several late to post-Variscan granitic intrusions completed the pre-Mesozoic evolution of the preAlpine basement gneisses and presumably led to the greenschist facies overprint in the host rocks. The resulting heterogeneities were intermediate to steep south- to SE-dipping fabrics (Berger et al., 2017b), which already formed before the initiation of the Alpine orogenic cycle and therefore represent important mechanical anisotropies for the Alpine tectonic evolution (Herwegh et al., 2017).

\subsection{Stratigraphic priming}

Some of the steep SE-orientated pre-Alpine heterogeneities were reactivated during the Mesozoic as normal faults within the Helvetic shelf of the Tethys Ocean (e.g., Hänni and Pfiffner, 2001). Strikingly, in the study area, the JSW (that should later act as a major thrust) is located at the preAlpine boundary between the ILZ and EZ. The SE-dipping orientation most likely resulted in the reactivation of these contacts as Jurassic normal faults, causing the stratigraphic NW-SE asymmetry in the Middle Jurassic (Herwegh and Pfiffner, 2005; Krayenbuhl and Steck, 2009). This allows us to account for the evolution across the former Helvetic shelf. Two important stratigraphic observations can be made in the Mesozoic of the Jungfrau tectonic sliver and associated shear zones: (i) the Triassic sequence is eroded to a deeper level towards paleo SE, owed to the asymmetric Liassic erosion (Alemannic land; Pfiffner, 2014; Rohr, 1926) and (ii) the subsequent sedimentation in the Middle Jurassic is governed by normal faulting, resulting in thicker sediment successions at deeper water conditions to the paleo SE. Apart from these differences (and the difference in the Lower Cretaceous), the post-rift sedimentary cover is rather similar in thickness and facies throughout the study area.

Generally, the autochthonous cover of the Aar Massif comprises a Mesozoic stratum resembling the northwesternmost facies of the Central Helvetic domain in the Lauterbrunnen valley (Bruderer, 1924; Masson et al., 1980; Herb, 1983). On a larger scale, our stratigraphic model aligns well with recent findings, e.g., for the Triassic (Gisler et al., 2007) and for the revised Tertiary stratigraphy of the Helvetic realm (Menkveld-Gfeller et al., 2016). This stratigraphic model (see Fig. 4 and Table 2) allows us to bracket the thicknesses of these units. We are aware of the partly large uncertainties on these values (sometimes up to $100 \%$ ), yet it is still useful for avoiding the reconstruction of unrealistic geometries.

\subsection{Structural imprint of the Alpine evolution}

\subsubsection{Early stage deformation under highest Alpine temperature conditions}

Alpine peak metamorphic conditions are constrained by the RSCM estimates to low temperature (sub-greenschist facies) conditions for the sedimentary cover and the immediate crystalline substratum. An upper temperature limit is provided by the RSCM data from the most internal part of the JSW (Table 3) at $\sim 320^{\circ} \mathrm{C}$. Since the bulk of the Mesozoic strata consists of limestones (Fig. 2), the temperature range for the deformation has a lower constraint of $150-250^{\circ} \mathrm{C}$, which governs the onset of the ductile deformation of calcite (Herwegh et al., 2005; Kennedy and White, 2001; Burkhard, 1993). These conditions align well with reported regional Alpine metamorphic gradients (e.g., Herwegh et. al., 2017; Niggli and Niggli, 1965). Only at temperatures as high as $\sim 300^{\circ} \mathrm{C}$ or above, onset of ductile deformation in quartz occurs, as can be inferred from the occurrence of dynamic recrystallization in form of bulging recrystallization (e.g., Stipp et al., 2002; Bambauer et al., 2009; Haertel and Herwegh, 2014). However, our quartz-rich basement rocks were mainly deformed in a semi-brittle manner (see. Sect. 4.2.1) as quartz and feldspar are mostly mechanically reduced in grain size within discrete shear zones (Fig. 3c). The mylonitic character is primarily owed to ductile behavior of micas, chlorites and the fine-grained polymineralic gauges (Wehrens et al., 2016, 2017).

Contrariwise, the calcite limestone-dominated sedimentary rocks were completely recrystallized, along with the growth of new micas in pelitic rocks, leading to a pervasive, bedding-parallel foliation (S1). We find thrusts (SZ1) that synchronously utilized weak layers of the Triassic as detachment horizons and Tertiary shales and sandstones as roof thrusts. In the case of the Triassic, the cellular dolomites, evaporites and shales (Fig. 4) represent mechanically weak lithologies, where strain can be easily localized upon thrusting (Pfiffner, 1993). Along these thrusts, the sedimentary cover was detached from their substratum and formed an 


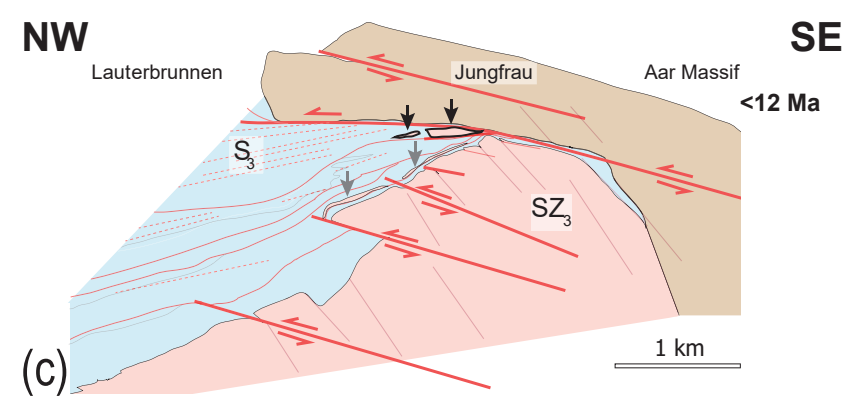

(b)
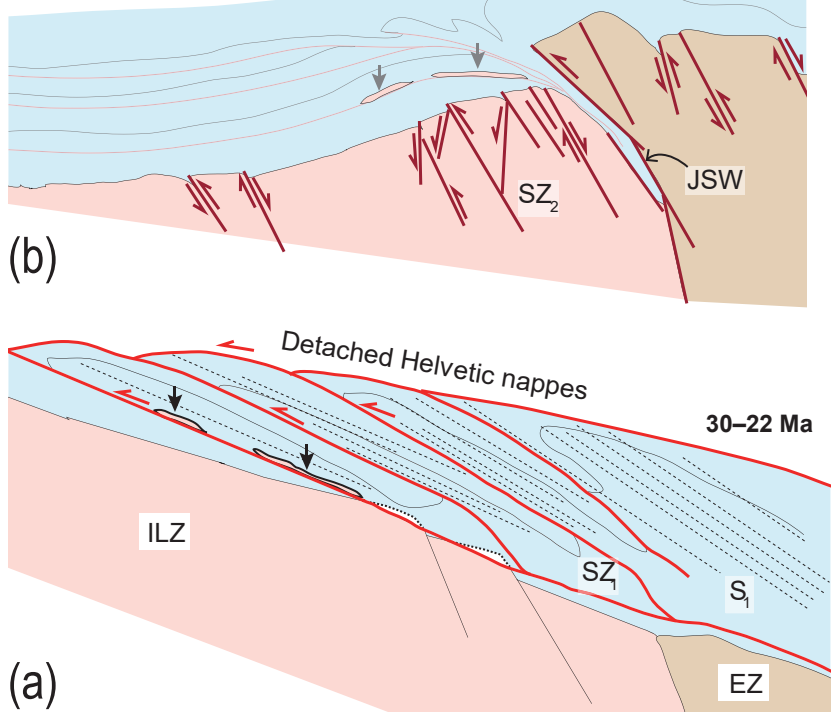

Figure 12. Schematic sketch of the evolution during the main deformation stages of the Alpine evolution. (a) In-sequence imbricate stacking during the late Kiental phase that induced S1 foliation and led to the incorporation of basement slabs into the sediment stack (black arrows). (b) Steep reverse faulting of SZ2 that induced folding in the cover during the Handegg phase. (c) SZ3 thrusts and S3 foliation in the sedimentary cover during the Pfaffenchopf phase along with a second generation of basement slabs incorporated into the sedimentary cover (black arrows).

imbricate stack (see Sect. 4.4, Fig. 12a). Initially, this occurred by reactivation of steep SE-dipping Jurassic normal faults as reverse thrusts, which was a common mechanism for the inversion of the Helvetic shelf during the formation of the Alpine accretion wedge (Krayenbuhl and Steck, 2009; Hänni and Pfiffner, 2001). These thrusts incorporated decameter-sized slivers of basement rocks at the base of sediment stacks by the means of footwall shortcut thrusts (McClay, 1992). The shortening accumulated along each of the imbricate thrusts amounted to several kilometers (Fig. 10).

This process most likely occurred during a final stage of the detachment of the Helvetic nappes further to the SE and thus during the late Kiental phase of deformation (Burkhard, 1988; Herwegh and Pfiffner, 2005; Pfiffner, 2014). This scenario clearly contradicts the interpretation of Krayenbuhl and
Steck (2009), who interpreted these structures as basement folds, since (i) we do not find signs for ductile folding in the basement rocks but rather the incorporation of large slices of basement rocks in the cover; and (ii) these sedimentary rocks are usually found in (thinned-out though) stacks within a normal stratigraphic succession. At the end of this deformation stage, the cover sedimentary units were imbricated and stacked upon each other.

\subsubsection{Exhumation structures}

The early deformation phase did not leave a pervasive imprint in the basement rocks. However, some deformation in the basement is locally manifested by the incorporation of the early basement slivers in the sediment imbricate stack (see black arrows in Fig. 12a). This situation changed dramatically during the next deformation stage. Here, the steep to subvertical SW-NE-striking shear zones in the basement rocks developed (SZ2). They generally exhibit a reverse fault character with upward movement of the southern block (Figs. 3, 11b). Such structures can be seen through the whole Aar Massif (Baumberger et al., 2018) and express the vertical extrusion of mid-crustal rocks during the Handegg phase (Herwegh et al., 2017; Wehrens et al., 2016, 2017). The large number and the dispersive distribution of these shear zones in combination with comparatively small offsets of a few centimeters to meters are characteristic and played an important role for the deformation in the sedimentary cover. There we find local small-scale folds (Fig. 7e) with a subvertical axial plane foliation (S2) in the JSW and just above the basement cover contact in the SE. The effect of the Handegg phase of vertical tectonics ended in the sedimentary cover units, where the localized shear zones in the basement were accommodated by (deca)meter-scale folding in the mechanically weaker sedimentary rocks (Middle Jurassic and Triassic; see Sect. 5.3.1) at their contacts with the basement rock. Therefore, this deformation phase did not affect the sedimentary nappe stack at higher tectonic levels by localized shear deformation (Fig. 11b). At the scale of the entire massif, however, the large-scale bulging of both the basement cover contact and the Helvetic nappe stack is in part related to this deformation stage.

Subsequent horizontal thrusting overprinted all aforementioned structures, producing a set of thrusts that are found both in the basement and cover rocks (SZ3). These thrusts cut into the cover rocks, most notable in the JSW. They further induced the formation of the mylonitic S3 foliation in the sedimentary rocks, still under ductile deformation conditions for calcite. This deformation corresponds to the Pfaffenchopf phase of Berger et al. (2017a) and Herwegh et al. (2017). It accommodated a significant amount ( $>2 \mathrm{~km}$ in the JSW; Fig. 11) of horizontal displacement, and the deformation was concentrated at several levels. During this phase, numerous and large slabs of basement gneisses were wedged into the sedimentary cover (see arrows in Fig. 12c). The presence 
of these has been known for almost a century (e.g., Scabell, 1926; Collet and Paréjas, 1931; Kammer, 1989), yet their origin and particular position have never been considered as a key to understanding the deformation style (Fig. 12c).

\subsubsection{Youngest structures}

The brittle deformation structures presented in Sect. 4.2 cut all older ones and affect the crystalline basement and the sedimentary cover alike, thus being clearly the youngest ones to be active. The steep NE-SW faults (F1; Fig. 9b) do not accommodate much offset and rather are present often as open, or partly filled, joint sets. They are strikingly similar to structures reported by Labhart (1966). Berger et al. (2017a) described these structures in the same geodynamic context but referred them as Gadmen phase structures. The (sub)vertical SE-NW-running faults (F2) reported in Sect. 4.2.1 show a complex history of deformation, with clear evidence for brittle deformation (cataclasites of serval generations and young fault gauges in the cores). Offsets at centimeter-to-meter scales allow us to identify strike-slip to oblique fault behavior. They have striking similarities with faults reported from the SW Aar Massif. According to Ustaszewski et al. (2007), these offsets record evidence for episodic cycles of brittle deformation and fluid pulses that formed the veins and cataclasites over millions of years. In addition, these faults were considered to offset Quaternary sequences (Ustaszewski et al., 2007) as well. However, both fault sets affect the crystalline basement and the sedimentary cover alike and do not feature large offsets. They are thus not considered of great importance for the structural style and the inferred deformation history.

\subsection{Geodynamic implications}

The deformation structures described in this work give highresolution insight in the processes that resulted in the exhumation of the ECM to its peculiar position at the Alpine front. First, the peak temperature estimations for the internal JSW $\left(<330^{\circ} \mathrm{C}\right)$ indicate a depth of $10.5-12 \mathrm{~km}$ during these conditions (assuming a geothermal gradient of $27^{\circ} \mathrm{C} \mathrm{km}^{-1}$ ). The onset of dynamic recrystallization in quartz in these rocks indicates that the first deformation occurred close to peak metamorphic conditions. This deformation produced the fabrics (SZ1, S1), which we link with the imbrication and the stacking of the sedimentary strata. These processes were also associated with the wedging of some basement rock lenses. Hence, this deformation marked the change from thin-skinned tectonics to thick-skinned deformation between 30 and > $22 \mathrm{Ma}$ (late Kiental phase of Burkhard, 1988) at the external European continental margin. It records the latest stage of shearing off of sedimentary nappes within the Alpine edifice (Schmid et al., 1996; Handy et al., 2010) and is dominated by horizontal shortening with a minor vertical component.
The following drastic change in tectonic style to vertical differential uplift through reverse/normal faulting produced mainly shear zones in the basement (SZ2) with only local folding in the sedimentary cover (axial plane foliation S2). These structures have been related to the Handegg phase of deformation (active between 22 and $>12 \mathrm{Ma}$ ) because of their striking similarity to structures in the Haslital and in the entire Aar Massif (e.g., Wehrens et al., 2016, 2017; Herwegh et al., 2017; Berger et al., 2017a). They accumulate vertical displacement up to $8 \mathrm{~km}$ in the southern Aar Massif (Herwegh et al., 2017; Wehrens et al., 2017, 2016) while little offset was accumulated in the NW rim of the Aar Massif (our study area). The sudden change from horizontal to vertical dominated tectonics is thought to be induced by buoyancy forces and slab steepening (Herwegh et al., 2017) on a larger scale and therefore related to the rollback subduction of the European lithospheric mantle slab (Schlunegger and Kissling, 2015; Kissling and Schlunegger, 2018).

Another change in tectonic style (back again to horizontal tectonics) produced the third, more localized deformation fabric (SZ3, S3). This NW-directed thrusting cuts and partially overprints older structures, which resembles the Pfaffenchopf phase (Wehrens et al., 2017; Herwegh et al., 2017). It is during this phase that a second set of large basement rock slabs was thrusted into the sedimentary cover. The localized thrust horizons, where a major thrust horizon was located within our JSW, contributed significantly to the uplift during the exhumation.

\section{Conclusions}

The linkage between the deformation structures in the Aar Massif basement and its sedimentary cover at the Aar Massif NW rim allows us to present a detailed picture of how bedrock with different lithologies responded to identical mechanisms under greenschist and lower-grade metamorphic conditions. In this context, we find that the key for a better understanding of the tectonic complexities lies in the finding of $T_{\max }<330^{\circ} \mathrm{C}$. It allows only for brittle deformation of feldspar, dolomite or iron carbonates, very limited semi-ductile deformation of quartz and entirely ductile deformation of calcite and phyllosilicates. This leads to ductile folding and thrusting in the calcite-dominated cover rocks (e.g., Upper Jurassic, Cretaceous) while in the quartz- and feldspar-dominated basement (i.e., the ILZ, EZ) semi-ductile shear zones were formed despite the bulk of the crystalline basement rocks reacting in a brittle manner to the same deformation. Based on this, we can disentangle the imprints of at least three deformation stages, each leaving different structures in the crystalline basement and the sedimentary cover. This enables us to refine the original two-phase subdivision (Kiental and Grindelwald phases) and allows us to link our observations with the recently published large-scale block extrusion model of the entire Aar Massif, governed by 
the change in plate driving forces in the lithospheric mantle. Lastly, we conclude that the multiphase deformation oriented the basement cover contact of the Aar Massif in a steep NW plunging manner. The deformation structures in combination with the uplift (especially the horizontal and vertical shear zones and foliations) set the stage for preferential erosion to produce the impressive morphology of the Jungfrau-Eiger mountains.
Data availability. Remote-sensing-derived lineaments used for Fig. 6a are provided as $x y z$ files with Swiss coordinates (CH1903) and included in the Supplement (Supplement S1).

All measured Raman spectra with intensity (in arbitrary units, second column) over Raman shift (in $\mathrm{cm}^{-1}$, first column) and used spectra for curve fitting (and Fig. B1 histograms) are indicated in the Excel sheet in the Supplement (Supplement S2). 


\section{Appendix A: Geological map compilation and Mesozoic lithostratigraphy}

The structural map (Figs. 1 and 10) was compiled from the following preexisting maps: Collet and Paréjas (1928), Günzler-Seifert and Wyss (1938) and the GeoCover maps: LK 1228, 1229, 1248 and 1249, which in turn were largely based on the former publications. The most recent maps of Pfiffner et al. (2011) and Berger et al. (2017b), which present the geological architecture at a regional scale, were considered as well. A set of profiles produced by Collet and Paréjas (1931) and Günzler-Seifert and Wyss (1938), Herb (1983) and Hänni and Pfiffner (2001) was used as a basis. However, the first sections by Collet and Paréjas (1931) and GünzlerSeifert and Wyss (1938) have not been georeferenced, with the consequence that the course of the section cannot be precisely allocated. Therefore, these profiles had first to be homogenized in structural style, georeferenced and integrated in our updated geological map.

The paleogeographical northwestern Late Permian to Early Triassic strata (Fig. 4) has been assigned to a terrestrial floodplain environment where the sediments were directly deposited on the weathered crystalline basement (Mels Fm.). This unit is then overlain by mixed siliciclasticcarbonaceous sediments and a sequence of dolomites, thus marking a tidal flat, sabkha-type of environment (Röti Fm.; Gisler et al., 2007). These Lower Triassic sedimentary rocks are preserved as quartzite, slate and dolomite (locally anhydrite bearing in the Röti Fm. and Mels Fm.). In the lowest tectonic level (equivalent to the cover of the most external part of the exhumed Aar Massif situated in the Lauterbrunnen valley), up to a $30 \mathrm{~m}$ thick suite of dolomites overlain with a suite of shales with up to $5 \mathrm{~m}$ thick dolomite beds, which have been assigned to the Röti Fm. and Quarten Fm., is preserved (Appendix Fig. A1; Bruderer, 1924). These sedimentary rocks (and possibly overlying units) were subject to erosion during the Late Triassic/Early Jurassic. This is recorded by $<1 \mathrm{~m}$ thick breccias (basal breccia) containing Röti dolomite components (Krebs, 1925; Frey, 1968). After the hiatus, a thin succession of ferrous sandstones intercalated with echinodermata-rich limestones was deposited. This unit, which has been assigned to the Bommerstein Fm. and Reischiben Fm., is $<10 \mathrm{~m}$ thick at the base of the Lauterbrunnen valley (Masson et al., 1980; Collet and Paréjas, 1931) and also contains a thin oolithic horizon that contains iron- and manganese-rich concretions. This formation is overlain by a suite of centimeter- to decimeterthick bedded, sandy to argillaceous limestones (Schilt Fm.). These gradually replaced the dark, micritic limestone upsection, referred to as the Quinten Fm. Deposition of this latter unit commenced in the lower Oxfordian, reaching an estimated thickness between 75 and $150 \mathrm{~m}$ in the study area (Collet and Paréjas, 1931). The Quinten unit itself is overlain by fossil-rich limestones (Öhrli Fm.) of varying thicknesses. These differences in preserved thicknesses are due to a Tertiary phase of erosion where stratigraphic columns were dissected to successively deeper levels from the NW to the SW. Iron-rich sandy to argillaceous infills in karst pockets combined with a few-meter-thick horizon of ironrich sandstones are documents of this erosional phase. Related fragments, most likely of pre-Priabonian to Eocene age, are referred to as "Siderolithic" (Herb, 1983; Wieland, 1979). Locally, it forms an up to $40 \mathrm{~m}$ thick suite of breccias with components of Quinten limestone, Öhrli limestone and Helvetic Kieselkalk (Wieland, 1979). The overlying calcareous breccia, known as "Mürren-Brekzie" with thicknesses of up to $80 \mathrm{~m}$ in the Eiger north face (GünzlerSeifert and Wyss, 1938; Collet and Paréjas, 1931), already chronicles the Priabonian transgression resulting in the deposition of the Niederhorn Fm. This unit is considered as equivalent of the Hohgant sandstone member (MenkveldGfeller et al., 2016). These clastic shoreface deposits are overlain by a limestone suite described as Lithothamnium limestone (Menkveld-Gfeller, 1994). Sandstone lenses and dark bituminous carbonates (most likely Gemmenalp limestone equivalents) become more frequently upsection and grade into a succession of marls alternated with siliciclastic turbidites and calciturbidites. These rocks were mapped as flysch (Collet and Paréjas, 1931), but we note here they have striking similarities with sedimentary rocks in the flank of the Schwarzmönch, the depositional ages of which have tentatively been assigned to the Priabonian (Günzler-Seifert and Wyss, 1938). Hence, it is debatable whether the attribution to the Stad Fm. or to the north Helvetic flysch group is correct.

Within the JSW, the sedimentary succession (Fig. 4) starts with a $<1 \mathrm{~m}$ thick Permian paleosol, which has also been encountered further to the west (Krayenbuhl and Steck, 2009). This is overlain by Triassic slates and sandstones attributed to the Mels Fm. and a $<2 \mathrm{~m}$ thick sequence of dolomites (Röti Fm.). Similar to the situation of the autochthonous cover, no Upper Triassic rocks are present, either due to non-sedimentation or to a phase of post-depositional erosion lasting until the Middle Jurassic (Masson et al., 1980). The succession of echinodermata-rich and iron-manganese nodules, deposited during Middle Jurassic times (Bommerstein Fm. and Reischiben Fm.), are considerably thicker than in the NW. This supports the inferred strong tectonic thinning of this unit $(\sim 10 \mathrm{~m}$ at Mönchsjoch, MJ; $\sim 5 \mathrm{~m}$ at the Eismeer/tunnel, ET; Collet and Paréjas, 1931). Similarly, the overlying sandy limestones of the Schilt Fm. are still thicker than $30 \mathrm{~m}$ (Fig. 3). The Upper Jurassic to Cretaceous limestones of the Quinten Fm. and Öhrli Fm. are generally missing within the JSW and have been displaced to the NW. As a consequence, they can be found in the middle part of the Eiger (Fig. 2), above the Eismeer/tunnel (ET) area and in the northern flank of the Mönch (Fig. 2). The entire sedimentary stack is strongly folded, foliated and thrusted, which leads to a doubling and to an inversion of the upper part, while the succession has been repeatedly stacked in other localities. 
Table A1. Basic data for selected samples used in Figs. 3 and 8. Thin section description for dominant dynamic quartz recrystallization mechanism (BLG: bulging), dominant mica and mica growth in shear zone (if applicable). Coordinates are given in the Swiss coordinate system (CH1903). For shear zone generation discussion, see Sect. 4.2.1. NA - not available.

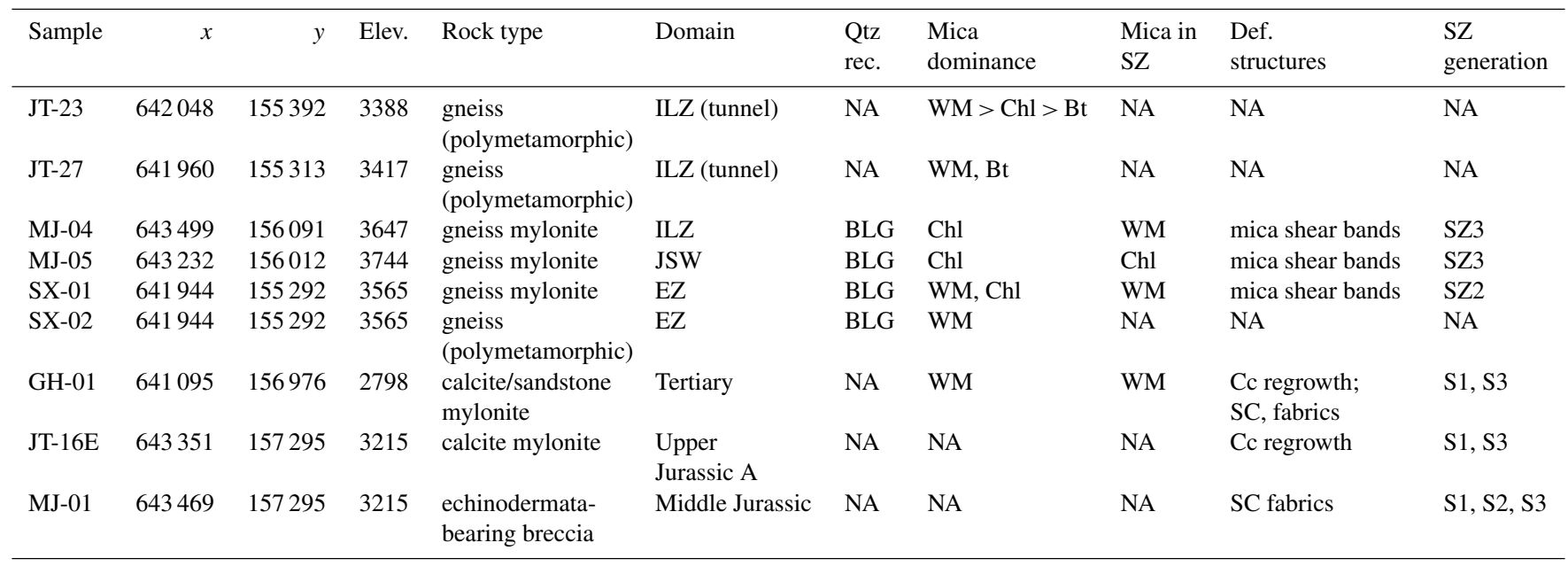
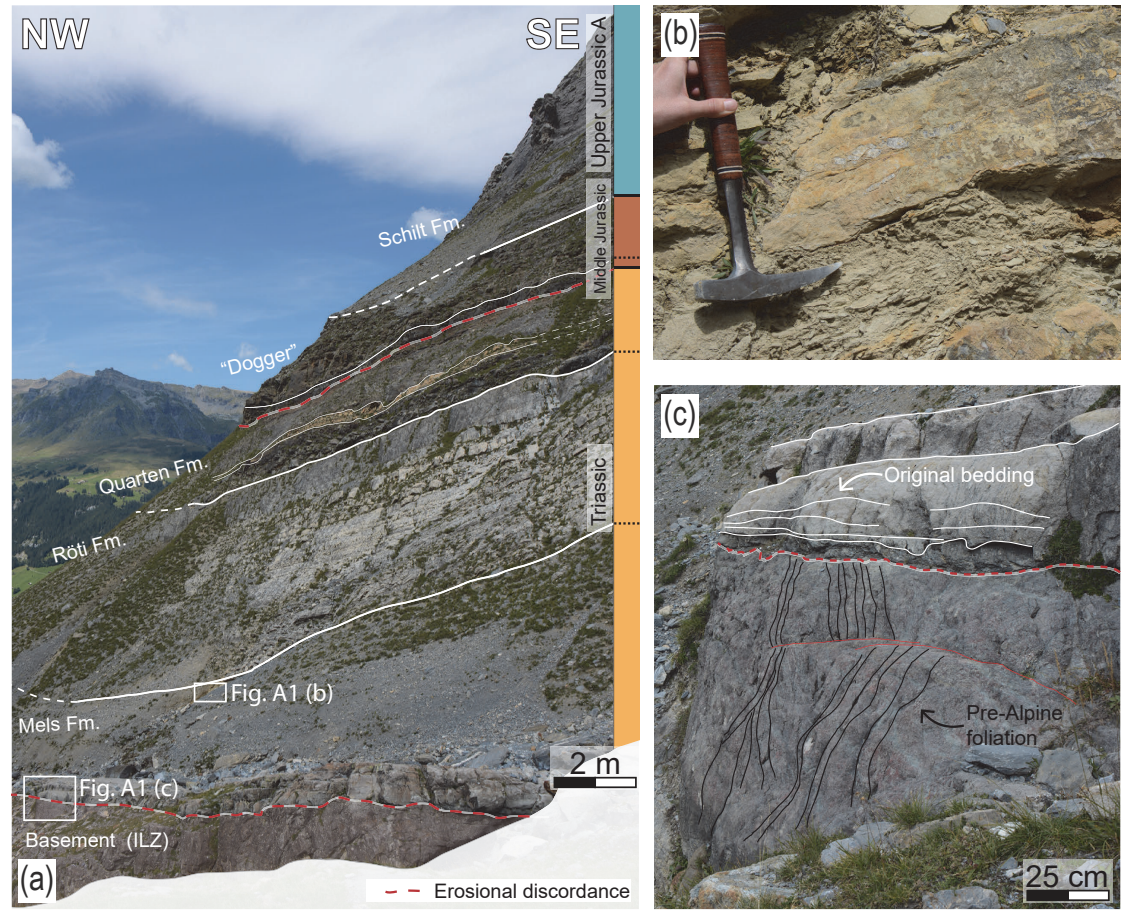

Figure A1. Undeformed basal stratigraphic section of the sedimentary cover of the ILZ in the Rottal (RT). 

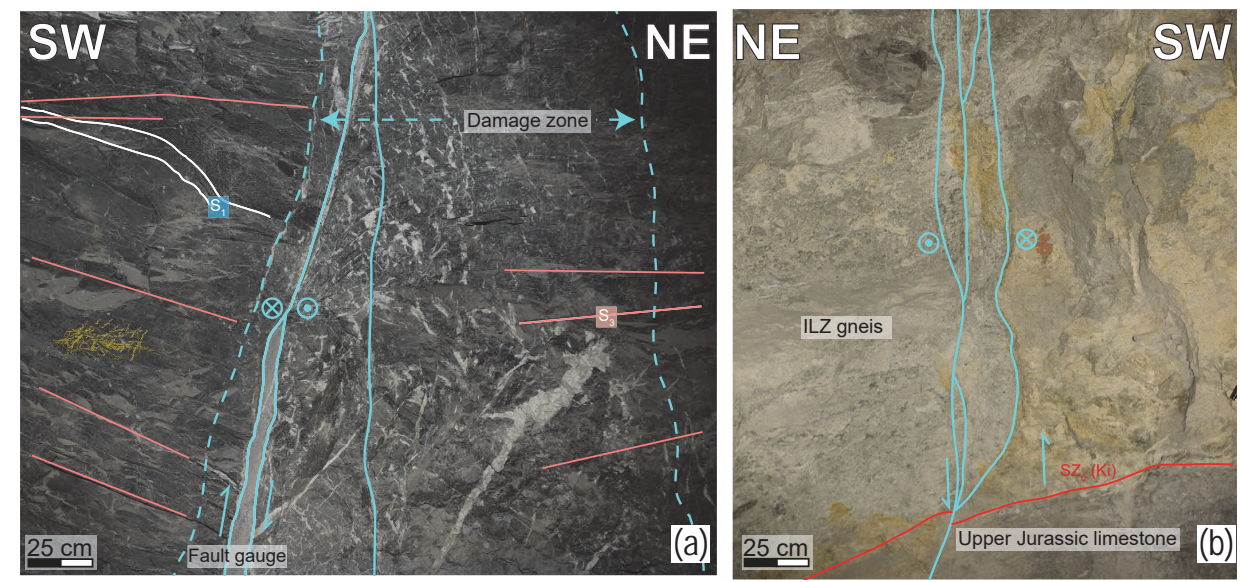

Figure A2. Youngest fault structures (F2) cross-cutting all previous structures in the sedimentary cover (a) and the basement (b) with an oblique to strike-slip behavior. 


\section{Appendix B: RSCM temperature estimate histograms}

Fitted Raman spectra distributions (Fig. B1) display reasonable Gaussian probability distributions with a maximum spread of $50^{\circ} \mathrm{C}$ (except for GH-01).
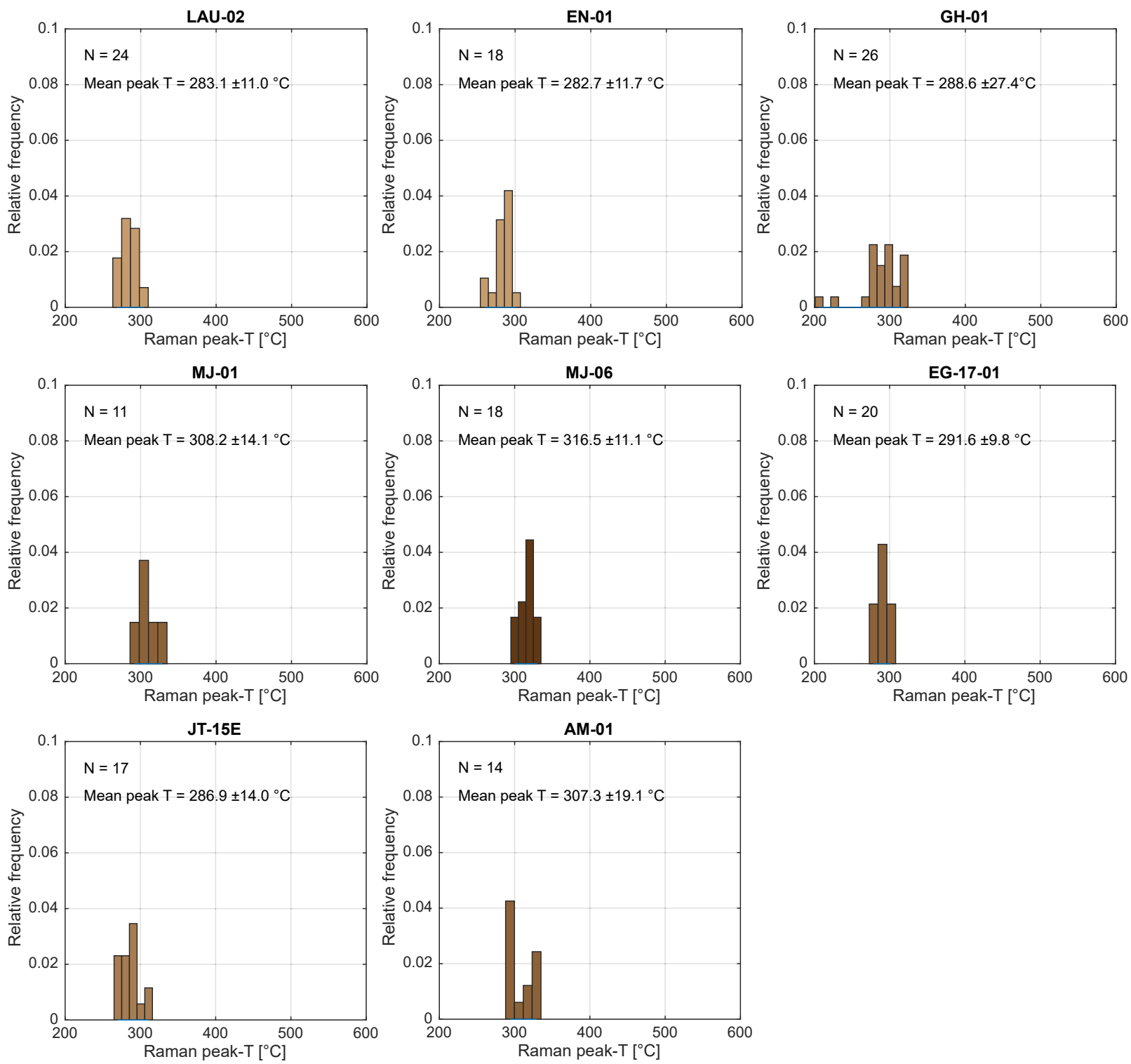

Figure B1. RSCM temperature estimate histograms for each sample for the fitted spectra. 


\section{The Supplement related to this article is available online at https://doi.org/10.5194/se-9-1099-2018-supplement.}

Author contributions. DM and FS designed the study, whereas DM and AL carried out fieldwork, and LN did the RSCM measurements. $\mathrm{DM}$ interpreted the data with additional scientific input from $\mathrm{MH}$. DM prepared the manuscript and figures with contributions from all co-authors.

Competing interests. The authors declare that they have no conflict of interest.

Acknowledgements. We thank the Jungfraubahn railway company, especially Stefan Michel, for their logistic support and access to the railway tunnel. We further thank the High Altitude Research Stations Jungfraujoch and Gornergrat (HFSJG) for making our fieldwork possible. We thank Midland Valley (now Petex) for providing an academic version of Move ${ }^{\mathrm{TM}}$, licensed to the Institute of Geological Sciences of the University of Bern. The research was supported by the Swiss National Science Foundation through grant no. 159299 awarded to Fritz Schlunegger. Alfons Berger is thanked for discussion about the basement rock units. We thank Franz Neubauer and an anonymous referee for insightful comments that improved the manuscript.

Edited by: Florian Fusseis

Reviewed by: Franz Neubauer and one anonymous referee

\section{References}

Abrecht, J.: Geologic units of the Aar massif and their pre-Alpine rock associations: a critical review, Schweiz. Miner. Petrog., 74, 5-27, https://doi.org/10.5169/seals-56328, 1994.

Baltzer, A.: Der mechanische Contact von Gneiss und Kalk im Berner-Oberland, Dalp, Bern, Switzerland, 255 pp., 1880.

Bambauer, H. U., Herwegh, M., and Kroll, H.: Quartz as indicator mineral in the Central Swiss Alps: the quartz recrystallization isograd in the rock series of the northern Aar massif, Swiss J. Geosci., 102, 345-351, https://doi.org/10.1007/s00015009-1319-z, 2009.

Baumberger, R.: Quantification of lineaments: Link between internal 3D structure and surface evolution of the Hasli valley (Aar massif, Central Alps, Switzerland), Diss. Univ. Bern, Bern, 2015.

Baumberger, R., Herwegh, M., and Kissling, E.: Remote sensing and field data based structural 3D modelling (Haslital, Switzerland) in combination with uncertainty estimation and verification by underground data, AGU Geophysical Monographs, in press, 2018.

Berger, A., Wehrens, P., Lanari, P., Zwingmann, H., and Herwegh, M.: Microstructures, mineral chemistry and geochronology of white micas along a retrograde evolution: An example from the Aar massif (Central Alps, Switzerland), Tectonophysics, 721, 179-195, https://doi.org/10.1016/j.tecto.2017.09.019, 2017a.
Berger, A., Mercolli, I., Herwegh, M., and Gnos E.: Geological Map of the Aar Massif, Tavetsch and Gotthard Nappes 1:100 000, Federal Office of Topography Swisstopo, Wabern, 2017b.

Beyssac, O., Goffé, B., Chopin, C., and Rouzaud, J. N.: Raman spectra of carbonaceous material in metasediments: a new geothermometer, J. Metamorph. Geol., 20, 859-871, https://doi.org/10.1046/j.1525-1314.2002.00408.x, 2002.

Bruderer, W.: Les sédiments du bord septentrional du Massif de l'Aar du Trias à l'Argovien, Thèse Sc., Lausanne, Switzerland, 86 pp., 1924.

Burkhard, M.: L'Helvétique de la bordure occidentale du massif de l'Aar (évolution tectonique et métamorphique), Eclogae Geol. Helv., 81, 63-114, https://doi.org/10.5169/seals-166171, 1988.

Burkhard, M.: Calcite twins, their geometry, appearance and significance as stress-strain markers and indicators of tectonic regime: a review, J. Struct. Geol., 15, 351-368, https://doi.org/10.1016/0191-8141(93)90132-T, 1993.

Challandes, N., Marquer, D., and Villa, I. M.: $P-T-t$ modelling, fluid circulation, and ${ }^{39} \mathrm{Ar}-{ }^{40} \mathrm{Ar}$ and $\mathrm{Rb}-\mathrm{Sr}$ mica ages in the Aar Massif shear zones (Swiss Alps), Swiss J. Geosci., 101, 269-288, https://doi.org/10.1007/s00015-008-1260-6, 2008.

Collet, L. and Paréjas, E.: Carte géologique de la chaîne de la Jungfrau, 1:25 000, Francke, Bern, 1928.

Collet, L. and Paréjas, E.: Géologie de la chaîne de la Jungfrau, Beiträge zur Geol. Karte der Schweiz, N.F. 63, Francke, Bern, 1931.

Escher von der Linth, A.: Erläuterung der Ansichten einiger Contact-Verhältnisse zwischen Krystallinischen Feldspathgesteinen und Kalk im Berner Oberlande, Petitpierre, Neuchâtel,, 13 pp., https://doi.org/10.3931/e-rara-19223, 1839.

Fernández, O.: Obtaining a best fitting plane through 3D georeferenced data, J. Struct. Geol., 27, 855-858, https://doi.org/10.1016/j.jsg.2004.12.004, 2005.

Frey, M.: Quartenschiefer, Equisetenschiefer und germanischer Keuper: ein lithostratigraphischer Vergleich, Eclogae Geol. Helv., 61, 141-156, https://doi.org/10.5169/seals-163586, 1968.

Frey, M. and Mählmann, F.: Alpine metamorphism of the Central Alps. Schweiz. Miner. Petrog., 79, 135-154, https://doi.org/10.5169/seals-60202, 1999.

Gisler, C., Hochuli, P. A., Ramseyer, K., Bläsi, H., and Schlunegger, F.: Sedimentological and palynological constraints on the basal Triassic sequence in Central Switzerland, Swiss J. Geosci., 100, 263-272, https://doi.org/10.1007/s00015-007-1225-1, 2007.

Glotzbach, C., Reinecker, J., Danišík, M., Rahn, M., Frisch, W., and Spiegel, C.: Thermal history of the central Gotthard and Aar massifs, European Alps: Evidence for steady state, long-term exhumation, J. Geophys. Res., 115, F03017, https://doi.org/10.1029/2009JF001304, 2010.

Günzler-Seifert, H. and Wyss, R.: Erläuterungen zum Kartenblatt Grindelwald, Geol. Kommision der schweiz. Naturforsch. Gesellschaft, Bern, 1938.

Haertel, M. and Herwegh, M.: Microfabric memory of vein quartz for strain localization in detachment faults: A case study on the Simplon fault zone, J. Struct. Geol., 68, 16-32, https://doi.org/10.1016/j.jsg.2014.08.001, 2014.

Handy, M. R., Schmid, S. M., Bousquet, R., Kissling, E., and Bernoulli, D.: Reconciling plate-tectonic reconstructions of Alpine Tethys with the geological-geophysical record of spread- 
ing and subduction in the Alps, Earth-Sci. Rev., 102, 121-158, https://doi.org/10.1016/j.earscirev.2010.06.002, 2010.

Hänni, R. and Pfiffner, O. A.: Evolution and internal structure of the Helvetic nappes in the Bernese Oberland, Eclogae Geol. Helv., 94, 161-171, https://doi.org/10.5169/seals-168886, 2001.

Herb, R.: Bericht über die Exkursion der Schweizerischen Geologischen Gesellschaft auf das Schilthorn vom 19. September 1982, Eclogae Geol. Helv., 76, 181-188, https://doi.org/10.5169/seals-165356, 1983.

Herwegh, M. and Pfiffner, O. A.: Tectono-metamorphic evolution of a nappe stack: A case study of the Swiss Alps, Tectonophysics, 404, 55-76, https://doi.org/10.1016/j.tecto.2005.05.002, 2005.

Herwegh, M., de Bresser, J. H. P., and ter Heege, J. H.: Combining natural microstructures with composite flow laws: an improved approach for the extrapolation of lab data to nature, J. Struct. Geol., 27, 503-521, https://doi.org/10.1016/j.jsg.2004.10.010, 2005.

Herwegh, M., Berger, A., Baumberger, R., Wehrens, P., and Kissling, E.: Large-Scale Crustal-Block-Extrusion During Late Alpine Collision, Sci. Rep., 7, 413, https://doi.org/10.1038/s41598-017-00440-0, 2017.

Kammer, A.: Alpidische Verformung des aarmassivischen Nordrandes, Schweiz. Miner. Petrog., 69, 37-53, https://doi.org/10.5169/seals-52775, 1989.

Kennedy, L. A. and White, J. C.: Low-temperature recrystallization in calcite: Mechanisms and consequences, Geology, 29, 1027-1030, https://doi.org/10.1130/00917613(2001)029<1027:LTRICM>2.0.CO;2, 2001.

Kissling, E. and Schlunegger, F.: Rollback Orogeny Model for the Evolution of the Swiss Alps, Tectonics, 37, 1097-1115, https://doi.org/10.1002/2017TC004762, 2018.

Krayenbuhl, T. and Steck, A.: Structure and kinematics of the Jungfrau syncline, Faflertal (Valais, Alps), and its regional significance, Swiss J. Geosci., 102, 441-456, https://doi.org/10.1007/s00015-009-1333-1, 2009.

Krebs, J.: Geologische Beschreibung der Blümlisalp-Gruppe, Beiträge zur Geol. Karte der Schweiz, N.F. 54, Francke, Bern, 1925.

Labhart, T. P.: Mehrphasige alpine Tektonik am Nordrand des Aarmassivs Beobachtungen im Druckstollen Trift-Speicherberg (Gadmental) der Kraftwerke Oberhasli AG, Eclogae Geol. Helv., 59, 803-830, https://doi.org/10.5169/seals-163395, 1966.

Labhart, T. P.: Aarmassiv und Gotthardmassiv - Sammlung geolog. Führer Nr. 63, Gebr. Bornträger, Berlin, Stuttgart, Germany, 1977.

Lünsdorf, N. K. and Lünsdorf, J. O.: Evaluating Raman spectra of carbonaceous matter by automated, iterative curve-fitting, Int. J. Coal Geol., 160-161, 51-62, https://doi.org/10.1016/j.coal.2016.04.008, 2016.

Lünsdorf, N. K., Dunkl, I., Schmidt, B. C., Rantitsch, G., and von Eynatten, H.: Towards a Higher Comparability of Geothermometric Data obtained by Raman Spectroscopy of Carbonaceous Material. Part I: Evaluation of Biasing Factors, Geostand. Geoanal. Res., 38, 73-94, https://doi.org/10.1111/j.1751908X.2013.00249.x, 2014.

Lünsdorf, N. K., Dunkl, I., Schmidt, B. C., Rantitsch, G., and von Eynatten, H.: Towards a Higher Comparability of Geothermometric Data Obtained by Raman Spectroscopy of Carbonaceous Material. Part 2: A Revised Geothermometer, Geostand.
Geoanal. Res., 41, 593-612, https://doi.org/10.1111/ggr.12178, 2017.

Masson, H., Herb, R., and Steck, A.: Helvetic Alps of Western Switzerland, Excusion no. 1, in: Geology of Switzerland - a guide book, Part B, Geological Excursions, edited by: Trümpy, R., 109-153, Wepf \& Co, Basel, 1980.

McClay, K. R.: Glossary of thrust tectonics terms, in: Thrust tectonics, edited by: McClay, K. R., 419-433, Chapman and Hall, London, UK, 1992.

Menkveld, J. W.: Der geologische Bau des Helvetikums der Innerschweiz, Diss. Univ. Bern, Bern, 1995.

Menkveld-Gfeller, U., Kempf, O., and Funk, H.: Lithostratigraphic units of the Helvetic Palaeogene: review, new definition, new classification, Swiss J. Geosci., 109, 171-199, https://doi.org/10.1007/s00015-016-0217-4, 2016.

Menkveld-Gfeller, U.: Die Wildstrubel-, die Hohgant- und die Sanetsch-Foramtion: Drei neue lithostratigraphische Einheiten des Eocaens der helvetischen Decken, Eclogae geol. Helv., 87, 789-809, https://doi.org/10.5169/seals-167477, 1994.

Milnes, A. G. and Pfiffner, O. A.: Structural development of the infrahelvetic complex, eastern Switzerland, Eclogae Geol. Helv., 70, 83-95, https://doi.org/10.5169/seals-164615, 1977.

Nibourel, L., Berger, A., Egli, D., Luensdorf, N. K., and Herwegh, M.: Large vertical displacements of a crystalline massif recorded by Raman thermometry, Geology, 46, 875-878, https://doi.org/10.1130/G45121.1, 2018.

Niggli, E. and Niggli, C.: Karten der Verbreitung einiger Mineralien der alpidischen Metamorphose in den Schweizer Alpen (Stilpnomelan, Alkali-Amphibol, Chloritoid, Staurolith, Disthen, Sillimanit), Eclogae Geol. Helv., 58, 335-368, https://doi.org/10.5169/seals-163268, 1965.

Oberhänsli, R., Schenker, F., and Mercolli, I.: Indications of Variscan nappe tectonics in the Aar Massif, Schweiz. Miner. Petrog., 68, 509-520, https://doi.org/10.5169/seals-52086, 1988.

Pfiffner, O. A.: The structure of the Helvetic nappes and its relation to the mechanical stratigraphy, J. Struct. Geol., 15, 511-521, https://doi.org/10.1016/0191-8141(93)90145-Z, 1993.

Pfiffner, O. A.: Geology of the Alps, 2nd ed., Wiley Blackwell, Oxford, 2014.

Pfiffner, O. A., Burkhard, M., Hänni, R., Kammer, A., Klligflied, A., Mancktelow, N. S., Menkveld, J. W., Ramsay, J. G., Schmid, S. M., and Zurbriggen, R.: Structural Map of the Helvetic Zone of the Swiss Alps, including Vorarlberg (Austria) and Haute Savoie (France), $1: 100000$, Special Geological Maps, Federal Office of Topography Swisstopo, Wabern, 2011.

Pollack, H. N. and Chapman, D. S.: On the regional variation of heat flow, geotherms, and lithospheric thickness, Tectonophysics, 38 , 279-296, https://doi.org/10.1016/0040-1951(77)90215-3, 1977.

Rahiman, T. I. H. and Pettinga, J. R.: Analysis of lineaments and their relationship to Neogene fracturing, SE Viti Levu, Fiji, Geol. Soc. Am. Bull., 120, 1544-1555, https://doi.org/10.1130/B26264.1, 2008.

Rohr, K.: Stratigraphische und tektonische Untersuchung der Zwischenbildungen am Nordrand des Aarmassivs (zwischen Wendenjoch und Wetterhorn), Beiträge zur Geol. Karte der Schweiz, N.F. 57, Francke, Bern, 1926.

Rolland, Y., Cox, S. F., and Corsini, M.: Constraining deformation stages in brittle-ductile shear zones from combined field mapping and ${ }^{40} \mathrm{Ar} /{ }^{39} \mathrm{Ar}$ dating: The structural evolution of the 
Grimsel Pass area (Aar Massif, Swiss Alps), J. Struct. Geol., 31, 1377-1394, https://doi.org/10.1016/j.jsg.2009.08.003, 2009.

Rutishauser, H.: Die quantitative Erfassung von Migmatiten im Aufschlussbereich (Erläutert am Beispiel des Lauterbrunner Kristallins), Schweiz. Miner. Petrog., 53, 99-124, https://doi.org/10.5169/seals-41375, 1973.

Rutishauser, H.: Flüssige Phasen im migmatitlschen LauterbrunnerKristallin (Aarmassiv, Alpen), Geol. Rundsch., 63, 560-571, https://doi.org/10.1007/BF01820831, 1974.

Sala, P., Pfiffner, O. A., and Frehner, M.: The Alpstein in three dimensions: fold-and-thrust belt visualization in the Helvetic zone, eastern Switzerland, Swiss J. Geosci., 107, 177-195, https://doi.org/10.1007/s00015-014-0168-6, 2014.

Scabell, W.: Beiträge zur Geologie der Wetterhorn-SchreckhornGruppe (Berner Oberland), Beiträge zur Geol. Karte der Schweiz, N.F. 57, Francke, Bern, 1926.

Schaltegger, U.: The evolution of the polymetamorphic basement in the Central Alps unravelled by precise U$\mathrm{Pb}$ zircon dating, Contrib. Mineral. Petr., 113, 466-478, https://doi.org/10.1007/BF00698316, 1993.

Schaltegger, U., Albrecht, J., and Corfu, F.: The Ordovician orogeny in the Alpine basement: constraints from geochronology and geochemistry in the Aar Massif (Central Alps), Schweiz. Miner. Petrog., 83, 183-195, https://doi.org/10.5169/seals-63144, 2003.

Schlunegger, F. and Kissling, E.: Slab rollback orogeny in the Alps and evolution of the Swiss Molasse basin, Nat. Commun., 6, 8605, https://doi.org/10.1038/ncomms9605, 2015.

Schlunegger, F. and Willett, S.: Spatial and temporal variations in exhumation of the central Swiss Alps and implications for exhumation mechanisms, Geol. Soc. London, Spec. Publ., 154, 157-179, https://doi.org/10.1144/GSL.SP.1999.154.01.07, 1999.

Schmid, S. M., Pfiffner, O. A., Froitzheim, N., Schönborn, G., and Kissling, E.: Geophysical-geological transect and tectonic evolution of the Swiss-Italian Alps, Tectonics, 15, 1036-1064, https://doi.org/10.1029/96TC00433, 1996.

Schmid, S. M., Fügenschuh, B., Kissling, E., and Schuster, R.: Tectonic map and overall architecture of the Alpine orogen, Eclogae Geol. Helv., 97, 93-117, https://doi.org/10.1007/s00015004-1113-x, 2004.

Schneeberger, R., de La Varga, M., Egli, D., Berger, A., Kober, F., Wellmann, F., and Herwegh, M.: Methods and uncertainty estimations of 3-D structural modelling in crystalline rocks: a case study, Solid Earth, 8, 987-1002, https://doi.org/10.5194/se8-987-2017, 2017.
Steck, A.: Die alpidischen Strukturen in den Zentralen Aaregranite des westlichen Aarmassivs, Eclogae Geol. Helv., 61, 19-48, https://doi.org/10.5169/seals-163584, 1968.

Steck, A.: Structures de déformations tertiaires dans les Alpes centrales (transversales Aar-Simplon-Ossola), Eclogae Geol. Helv., 77, 55-100, https://doi.org/10.5169/seals-165499, 1984.

Stipp, M., Stünitz, H., Heilbronner, R., and Schmid, S. M.: Dynamic recrystallization of quartz: correlation between natural and experimental conditions, Geol. Soc. London, Spec. Publ., 200, 171-190, https://doi.org/10.1144/GSL.SP.2001.200.01.11, 2002.

Strasser, A.: Fazielle und sedimentologische Entwicklung des Betlis-Kalkes (Valanginian) im Helvetikum der Zentral- und Ostschweiz, Eclogae Geol. Helv., 75, 1-21, https://doi.org/10.5169/seals-165212, 1982.

Ustaszewski, M., Herwegh, M., McClymont, A. F., Pfiffner, O. A., Pickering, R., and Preusser, F.: Unravelling the evolution of an Alpine to post-glacially active fault in the Swiss Alps, J. Struct. Geol., 29, 1943-1959, https://doi.org/10.1016/j.jsg.2007.09.006, 2007.

Valla, P. G., Rahn, M., Shuster, D. L., and van der Beek, P. A.: Multi-phase late-Neogene exhumation history of the Aar massif, Swiss central Alps, Terra Nova, 28, 383-393, https://doi.org/10.1111/ter.12231, 2016.

Wehrens, P., Berger, A., Peters, M., Spillmann, T., and Herwegh, M.: Deformation at the frictional-viscous transition: Evidence for cycles of fluid-assisted embrittlement and ductile deformation in the granitoid crust, Tectonophysics, 693, 66-84, https://doi.org/10.1016/j.tecto.2016.10.022, 2016.

Wehrens, P., Baumberger, R., Berger, A., and Herwegh, M.: How is strain localized in a meta-granitoid, mid-crustal basement section? Spatial distribution of deformation in the central Aar massif (Switzerland), J. Struct. Geol., 94, 47-67, https://doi.org/10.1016/j.jsg.2016.11.004, 2017.

Wieland, B.: Zur Diagnese und schwachen Metamorphose eozaener siderolithischer Gesteine des Helvetikums, Schweiz, Miner. Petrog., 59, 41-66, https://doi.org/10.5169/seals-46042, 1979.

Xu, L., Renner, J., Herwegh, M., and Evans, B.: The effect of dissolved magnesium on creep of calcite II: Transition from diffusion creep to dislocation creep, Contrib. Mineral. Petr., 157, 339-358, https://doi.org/10.1007/s00410-008-0338-5, 2009. 